\title{
Size-resolved CCN distributions and activation kinetics of aged continental and marine aerosol
}

\author{
A. Bougiatioti ${ }^{1}$, A. Nenes ${ }^{2,3,4}$, C. Fountoukis ${ }^{3,4}$, N. Kalivitis ${ }^{1}$, S. N. Pandis ${ }^{4,5}$, and N. Mihalopoulos ${ }^{1,4}$ \\ ${ }^{1}$ Environmental Chemical Processes Laboratory, Department of Chemistry, University of Crete, Voutes, 71003, \\ Heraklion, Greece \\ ${ }^{2}$ Earth and Atmospheric Sciences, Georgia Institute of Technology, Atlanta, GA, 30332, USA \\ ${ }^{3}$ Chemical and Biomolecular Engineering, Georgia Institute of Technology, Atlanta, GA, 30332, USA \\ ${ }^{4}$ Institute of Chemical Engineering and High Temperature Chemical Processes (ICE-HT), Foundation for Research and \\ Technology Hellas (FORTH), Patras, 26504, Greece \\ ${ }^{5}$ Department of Chemical Engineering, Carnegie Mellon University, Pittsburgh, PA, 15213, USA
}

Received: 15 March 2011 - Published in Atmos. Chem. Phys. Discuss.: 21 April 2011

Revised: 16 August 2011 - Accepted: 17 August 2011 - Published: 30 August 2011

\begin{abstract}
We present size-segregated measurements of cloud condensation nucleus (CCN) activity of aged aerosol sampled at Finokalia, Crete, during the Finokalia Aerosol Measurement Experiment of summer 2007 (FAME07). From analysis of the data, hygroscopicity and activation kinetics distributions are derived. The $\mathrm{CCN}$ are found to be highly hygroscopic, (expressed by a size- and time- averaged hygroscopicity parameter $\kappa \sim 0.22$ ), with the majority of particles activating at $\sim 0.5-0.6 \%$ supersaturation. Air masses originating from Central-Eastern Europe tend to be associated with higher $\mathrm{CCN}$ concentrations and slightly lower hygroscopicity $(\kappa \sim 0.18)$ than for other airmass types. The particles were always well mixed, as reflected by the high activation ratios and narrow hygroscopicity distribution widths. Smaller particles $(\sim 40 \mathrm{~nm})$ were found to be more hygroscopic $(\sim 0.1 \kappa$ units higher) than the larger ones $(\sim 100 \mathrm{~nm})$. The particles with diameters less than $80 \mathrm{~nm}$ exhibited a diurnal hygroscopicity cycle (with $\kappa$ peaking at $\sim 14 \mathrm{~h}$ local time), consistent with photochemical aging and volatilization of less hygroscopic material from the aerosol. Use of bulk chemical composition and the aerosol number distribution results in excellent CCN closure when applying Köhler theory in its simplest form. Using asymptotic and threshold droplet growth analysis, the "aged" organics present in the aerosol were found not to suppress or delay the water uptake kinetics of particles in this environment.
\end{abstract}

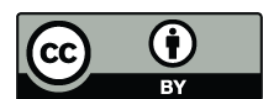

Correspondence to: A. Nenes (athanasios.nenes@gatech.edu)

\section{Introduction}

Predicting the global distribution of cloud condensation nuclei $(\mathrm{CCN})$ is required for an improved understanding of aerosol-cloud-climate interactions (IPCC, 2007). Recent studies address the relative importance of aerosol size distribution, particle composition and mixing state on predictions of CCN concentrations (Cubison et al., 2008; Roberts et al., 2002; Ervens et al., 2005; Dusek et al., 2006; Quinn et al., 2008). These studies help evaluate theory and also quantify $\mathrm{CCN}$ prediction error associated with simplifications taken to calculate $\mathrm{CCN}$ in indirect effect studies; if propagated through a global model simulation of the aerosol indirect effect, this error can be expressed as an indirect forcing uncertainty (Sotiropoulou et al., 2006, 2007).

Many of the recent CCN studies have focused on the impact of organic compounds in the aerosol phase. These organics due to their chemical complexity and abundance in global ambient aerosol (Zhang et al., 2007) introduce uncertainties in predictions of CCN concentrations. Laboratory experiments suggest that the solubility of organic-rich particles in water is important for their CCN activity (Cruz and Pandis, 1997; Bilde and Svenningsson, 2004), although residual water, inorganic water uptake, mutual deliquescence and metastable states may allow sparingly-soluble organic material to be available for activation as if they were completely soluble in water (Chang et al., 2007; Raymond and Pandis, 2002, 2003; Broekhuizen et al., 2004; Padró et al, 2006; Marcolli et al., 2006; Chang et al., 2007; Bilde and Svenningsson, 2004). The existence of surfactants that depress surface tension has also been shown to enhance $\mathrm{CCN}$

Published by Copernicus Publications on behalf of the European Geosciences Union. 
activity (e.g., Kuwata et al., 2008; Moore et al., 2008; AsaAwuku et al., 2008; Padró et al., 2010). Despite these effects, the converging view is that the compositional complexity of organic aerosol tends to yield material with little variability in hygroscopicity, so that bulk chemical metrics of the organic phase (such as oxidation state) may serve as an indicator of its CCN activity (Jimenez et al., 2009).

In lieu of the above, single-parameter approaches, such as the hygroscopicity parameter, $\kappa$, (Petters and Kreidenweis, 2007) have been effectively used to parameterize the cumulative effect of organics on the solute term of Köhler theory (the theoretical basis of most approaches used to describe $\mathrm{CCN}$ activity). Typical values of this parameter are $\kappa=0$ for insoluble wettable materials that do not significantly affect water activity via adsorption (Kumar et al., 2009, 2010), $\sim 0.1$ for oxidized secondary organic aerosols (Engelhart et al., 2008, 2011; Duplissy et al., 2008; Petters and Kreidenweis, 2007; Asa-Awuku, 2008, 2009; King et al., 2010), 0.6 for ammonium sulfate and nitrate, $0.95-1$ for sea salt (Niedermeier et al., 2008) and $\sim 1.25$ for pure sodium chloride particles (Rose et al., 2010). The effective hygroscopicity parameter of multicomponent aerosols can be approximated by a volume-weighted average of the $\kappa$-values of the individual chemical components (Kreidenweis et al., 2008; Gunthe et al., 2009). Continental and marine aerosols tend to cluster around $\kappa \sim 0.3$ and $\kappa \sim 0.7$, respectively (Andreae and Rosenfeld, 2008; Kreidenweis et al., 2008; Pöschl et al., 2009), with a fair amount of variability across space and time, depending on the organic mass fraction (e.g., Gunthe et al., 2009; Dusek et al., 2009, Cerully et al., 2011), relative abundance of ammonium sulfate (Cerully et al., 2011; Mochida et al., 2008, 2010) as well as the particle size (Wiedensohler et al., 2009; Rose et al., 2010). Furthermore, the mixing of non-hygroscopic primary organic aerosol (POA) and black carbon (BC) particles with photochemically produced hygroscopic species take place in a few hours during daytime, suggesting that away from primary sources, the number concentration of CCN may be predicted accurately enough for climate model applications assuming an internal mixture and using only the bulk chemical composition (Medina et al., 2007; Lance et al., 2009; Sotiropoulou et al., 2006, 2007; Wang et al., 2010).

Size-resolved CCN activity measurements can also be used to infer the origin of the observed hygroscopicity in ambient (and compositionally complex) aerosol samples, primarily through characterization of their water-soluble (WS) fraction. Padró et al. (2007) first introduced the method of Köhler Theory Analysis (KTA) to infer the molar volume and solubility of organic compounds from size-resolved $\mathrm{CCN}$ activity of aerosol generated from atomization of an aqueous solution and demonstrated its applicability to samples of known composition. Moore et al. (2008) extended KTA to include an inference of molar volume and surfactant characteristics for marine organic matter isolated from seawater collected near the Georgia coast. The analysis re- vealed that the solute contribution was negligible and the primary effect of the organic matter on CCN activity is through its impact on surface tension. When this analysis was applied to WS extracts of secondary organic aerosol (SOA) from biogenic and anthropogenic parent hydrocarbons (Engelhart et al., 2008, 2011; Asa-Awuku, 2009, 2010), a remarkably constant $\kappa$ emerged $(0.15 \pm 0.08$ when surface tension effects are deconvoluted, $\sim 0.3$ when they are implicitly included in the $\kappa$ calculation). Analysis of the WS fraction from biomass burning (Asa-Awuku et al., 2008) also revealed a similar hygroscopicity parameter $(\kappa \sim 0.3)$. Padró et al. (2010) determined the hygroscopicity of the WS fraction of Mexico City aerosol collected during MILAGRO-2006; $\kappa$ was $0.28 \pm 0.06$ and remained fairly constant regardless of location and organic fraction, reflecting a compensation between shifts in molar volume and surface tension depression. All together, these studies suggest that the hygroscopicity of oxidized organic aerosol may be predicted solely from knowledge of the water-soluble fraction of the material. Bougiatioti et al. (2009) tested this postulation for Eastern Mediterranean $\mathrm{CCN}$ and found that predictions of $\mathrm{CCN}$ notably improved when using the measured WS fraction and a prescribed $\kappa=0.3$. Given the correlation between the latter and the WS fraction of organic aerosol (Weber et al., 2007; Hennigan et al., 2009), the constant value seen for WS $\kappa$ may give rise to the observed correlation between the oxidation state and $\kappa$ of organic aerosol (Jimenez et al., 2009).

Another uncertain aspect of cloud droplet formation is the impact of slowly-dissolving compounds, droplet surface films and aerosol amorphous states on the activation kinetics of CCN. If prevalent, these kinetic limitations could have an important impact on cloud droplet number and size distribution (e.g., Chuang et al., 1997; Nenes et al., 2001a, 2002; Lance et al., 2004). Observational studies on the activation kinetics of ambient or complex CCN (e.g., Moore et al., 2008; Ruehl et al., 2008, 2009; Sorooshian et al., 2008; Lance et al., 2009; Padró et al., 2010; Cerully et al., 2011) have tested this hypothesis by comparing the size of activated droplets (from the $\mathrm{CCN}$ in question) against those obtained from calibration salt aerosol (used as a standard of rapid activation). Differences in droplet sizes can be used to detect kinetic limitations and can be parameterized as changes in the water vapor uptake coefficient, as long as the concentration of CCN in the instrument is not high enough to deplete supersaturation (Lathem et al., 2011). Evidence to date suggests that dry organic-rich aerosol with low hygroscopicity may exhibit activation delays, while aerosol rich in inorganic salts or water-soluble organic carbon tends to exhibit rapid activation kinetics (Moore et al., 2008; Ruehl et al., 2008; Shantz et al., 2008; Asa-Awuku et al., 2009, 2011; Padró et al., 2010; Cerully et al., 2011). Size-resolved droplet growth analysis data provides information on the kinetic heterogeneity of $\mathrm{CCN}$, allowing for the determination of kinetic parameter distributions (Ruehl et al., 2008, 2009) which would not necessarily be seen when applying "Threshold Droplet 
Growth Analysis" (TDGA) on polydisperse CCN measurements (Bougiatioti et al., 2009).

The Eastern Mediterranean is a climatically sensitive area of the globe. Aerosols play an important role, with a top of the atmosphere radiative cooling up to five times larger than warming from greenhouse gases (Vrekoussis et al., 2005). In the summertime, the combination of anthropogenic aerosol inflow, the scarcity of precipitation and persistently high $\mathrm{RH}$ values in the area can result in doubling (or more) of the total aerosol light scattering compared to winter (Kalivitis et al., 2007). The organic aerosol is always in a highly oxidized state, regardless of the aerosol source region (Hildebrandt et al., 2010), with about $70 \%$ of the total organic mass being water-soluble (Bougiatioti et al., 2009). Earlier work has shown that most of the aerosol in this region activates at $0.6 \%$ supersaturation, characteristic of the aged nature of the aerosols; $\mathrm{CCN}$ calculations using the simplest form of Köhler theory (i.e., size-invariant composition, and insoluble organic fraction) agrees with measurements to within $10 \%$ (for supersaturations between 0.2 and $0.73 \%$ ). Based on the aerosol "bulk" composition, an average $\kappa$ of $0.24 \pm 0.08$ is found for the aerosol at Finokalia (Bougiatioti et al., 2009). The variation of CCN properties with size however is still unknown and was postulated to explain the supersaturation-dependent $\mathrm{CCN}$ closure bias seen in Bougiatioti et al. (2009). The present study addresses this issue and presents size-resolved CCN activity measurements and characteristics of Eastern Mediterranean atmospheric aerosols during the Finokalia Aerosol Measurement Experiment - 2007 (FAME07) campaign. The focus of the subsequent analysis is on the size-dependant hygroscopicity, mixing state and activation kinetics of the aerosol.

\section{Observational data set}

\subsection{Measurement site}

Measurements took place at the Finokalia station $\left(35^{\circ} 32^{\prime} \mathrm{N}\right.$, $25^{\circ} 67^{\prime} \mathrm{E}$; http://finokalia.chemistry.uoc.gr) of the University of Crete and constituted part of the Finokalia Aerosol Measurement Experiment - 2007 (FAME07) campaign (Bougiatioti et al., 2009). A more detailed description of the site can be found in Mihalopoulos et al. (1997) and Sciare et al. (2003). This study focuses on the period during which size-resolved measurements of CCN were carried out (July to mid-August). HYSPLIT backtrajectory analysis (www.arl. noaa.gov/ready/hysplit4.html) showed that throughout the campaign a diversity of air masses was sampled, with influences from Europe, the former Soviet Union and Asia Minor (Fig. 1a, b) to air masses with less anthropogenic influence originating from the marine boundary layer or the free troposphere (Fig. 1c, d).

\subsection{Instrumentation}

Prior to measurement, the ambient aerosol was dried down to $\sim 5 \%$ relative humidity $(\mathrm{RH})$ with Silica-gel diffusional dryers (Fig. 2); this ensures that particle sizing is not affected by residual aerosol water, which can bias the analysis of CCN activity data for very acidic particles (Murphy et al., 2008). The dried particles were subsequently charged by passing through a Kr-85 bipolar charger (TSI Model 3077) and classified by electrical mobility with a Differential Mobility Analyzer (DMA; TSI Model 3081). The DMA was operated at a $10: 1$ sheath-to-aerosol flow ratio $\left(6\right.$ and $0.61 \mathrm{~min}^{-1}$ for the sheath and aerosol flows, respectively). The classified aerosol was then split into two streams, one sent to a Condensation Particle Counter (TSI Model 3010) to measure their concentration and the other to a Continuous Flow Streamwise Thermal Gradient CCN Chamber (CFSTGC; Roberts and Nenes, 2005; Lance et al., 2006) to measure the number of particles which act as CCN. The flows at the CPC and CFSTGC were monitored throughout the campaign. The activated droplets in the CFSTGC are counted and sized at the exit of its growth chamber with an Optical Particle Counter (OPC) that detects droplets and classifies them into 20 size bins (with diameter ranging from 0.7 to $10 \mu \mathrm{m}$ ). During the campaign, two flow configurations were used (Fig. 2) which differed as to the point of entry of the filtered make-up air flow. In the first configuration (Fig. 2a) a make-up flow of $0.751 \mathrm{~min}^{-1}$ is supplied to the classified aerosol stream before splitting the stream for the CPC and the CCN instrument. The second configuration was used after 8 August (Fig. 2b) and involved introducing the make-up flow to the aerosol stream supplied to the CPC. This was done to reduce the CFSTGC measurement uncertainty due to low particle concentrations (Moore et al., 2010).

The instruments were operated in Scanning Mobility CCN Analysis mode (SMCA; Moore et al., 2010), where the DMA voltage is continuously cycled between a minimum and maximum value and the time series of $\mathrm{CN}$ and $\mathrm{CCN}$ concentrations are recorded. The particle size distribution is then obtained from the $\mathrm{CN}$ timeseries of a scan cycle using wellestablished SMPS inversion techniques (e.g., Wang and Flagan, 1989). The same inversion procedure is applied to the CCN timeseries to obtain the CCN size distribution and the size-resolved "activation fraction" (ratio of of $\mathrm{CCN}$ concentration to $\mathrm{CN}$ concentration) and the droplet size from activated $\mathrm{CCN}$ as a function of mobility diameter. Multiple charge corrections were applied to the $\mathrm{CCN}$ inversion, as detailed in Moore et al. (2010).

Throughout the campaign, the CFSTGC was operated at a total flow rate of $0.51 \mathrm{~min}^{-1}$, with a sheath-to-aerosol flow ratio of 10:1, and a top-bottom column difference, $\Delta T$, between 4 and $15 \mathrm{~K}$. CCN concentrations were measured at each supersaturation for $6 \mathrm{~min}$, yielding sizeresolved $\mathrm{CCN}$ activation curves that cycled through 5 different supersaturations every $30 \mathrm{~min}$. Calibration of the 

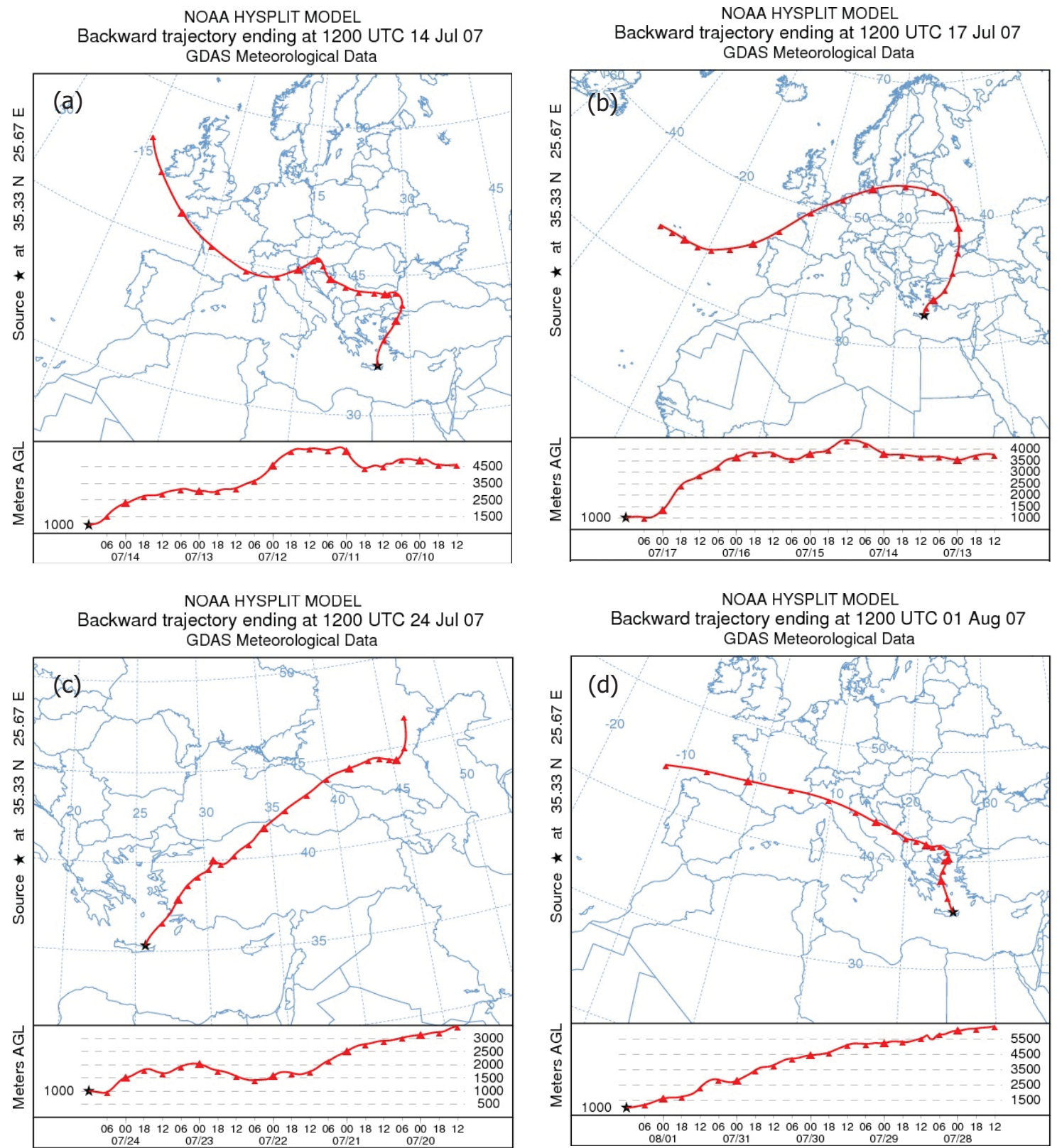

Fig. 1. Maps indicating the location of the sampling site and three-day HYSPLIT back trajectories for characteristic types of air masses sampled during FAME07: (a) 14 July 2007, (b) 17 July 2007, (c) 24 July 2007, and (d) 1 August 2007.

instrument supersaturation was attained with the use of classified $\mathrm{NaCl}$ aerosol and following the procedure of Bougiatioti et al. (2009). The CCN instrument was calibrated at the beginning and the end of the measurement campaign and was found to have very little variability between them (Bougiatioti et al., 2009). For the lower supersaturations (0.2 and $0.38 \%$ ), the relative variability in instrument supersaturation did not exceed $1 \%$ between calibrations, whereas for the highest supersaturation $(0.73 \%)$ the variability was under $3 \%$ (Bougiatioti et al., 2009).

\subsection{Aerosol chemical composition and size distribution}

A Scanning Mobility Particle Sizer (SMPS) was used to measure the particle size distribution for mobility diameters between 20 and $460 \mathrm{~nm}$ by placing them in 100 bins and using a sheath-to-aerosol ratio of 10:1. The SMPS consists of a scanning Differential Mobility Analyzer (DMA) running in series with a Condensation Particle Counter (CPC) for which a complete distribution is obtained every $3 \mathrm{~min}$. The total aerosol concentration $(\mathrm{CN})$ was measured by a Condensation Particle Counter (CPC; TSI model 3010) with a $50 \%$ particle detection efficiency at $10 \mathrm{~nm}$ diameter. 


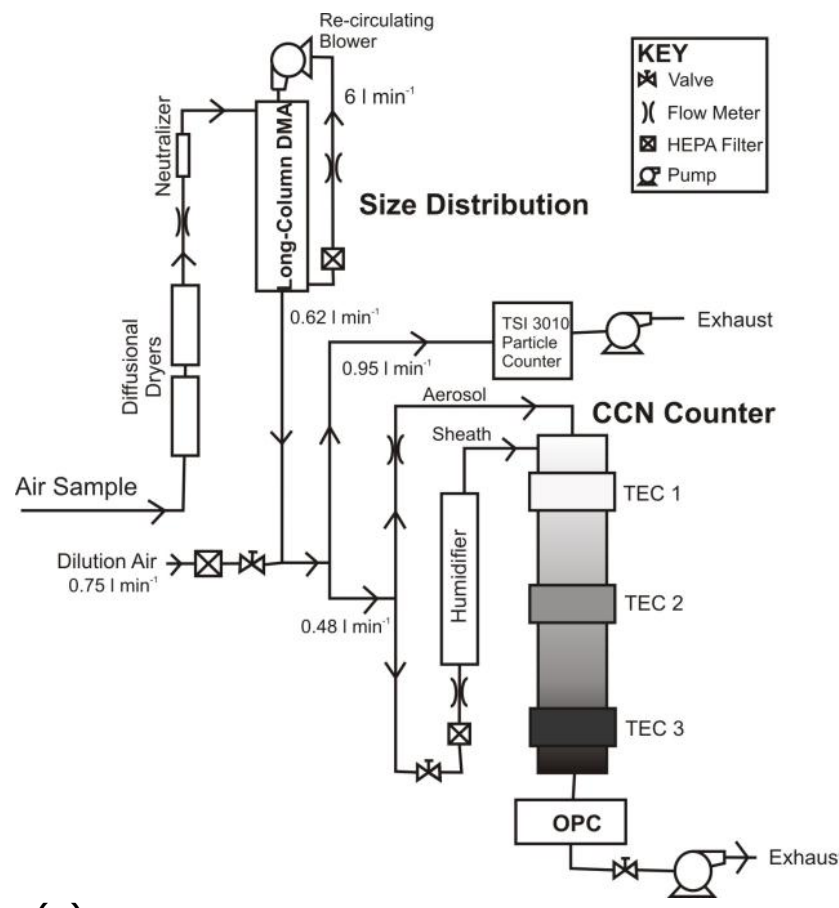

(a)

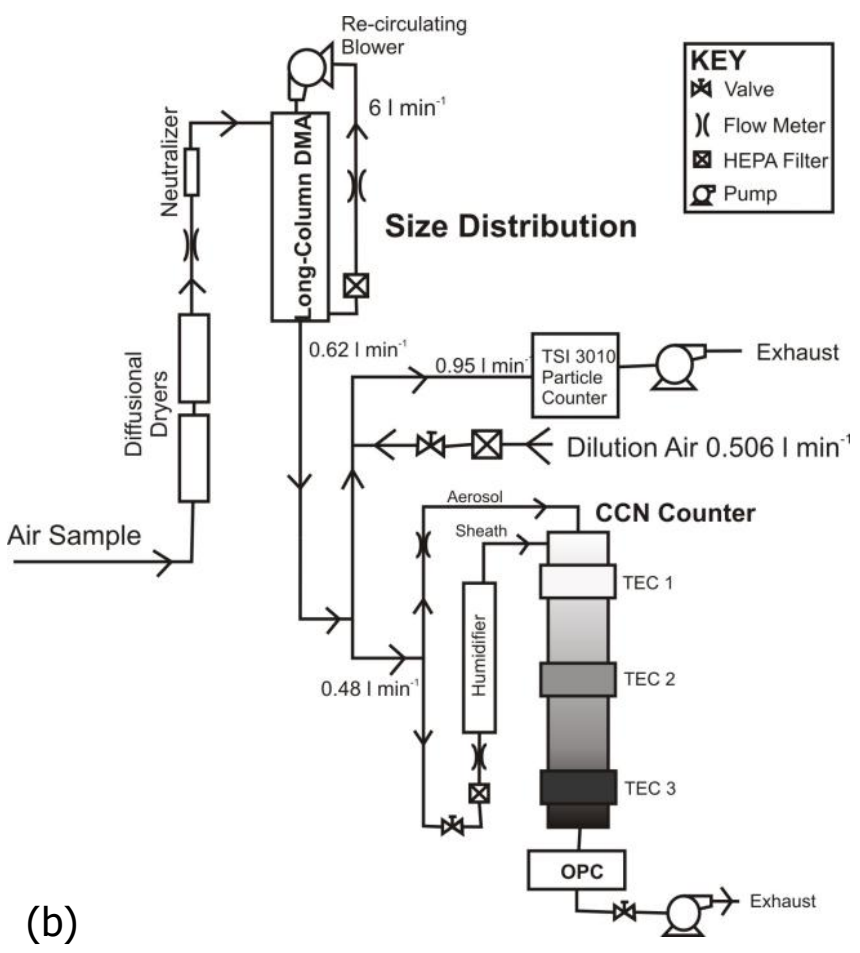

Fig. 2. Schematic of the setup used for the size-resolved CCN measurements.

\subsection{Analysis of SMCA data}

Each constant supersaturation segment ( 6-min long) was screened to minimize observational biases and examined for minimal fluctuations in the CFSTGC flow chamber temperature gradient and stability of the flows (data exhibiting maximum temperature deviation of more than $15 \%$ from the setpoint are discarded). The size-dependant activation ratio function, $R_{\mathrm{a}}\left(d_{\mathrm{p}}\right)$, is then determined by computing the ratio of CCN over CN concentration as a function of dry particle diameter. $R_{\mathrm{a}}\left(d_{\mathrm{p}}\right)$ is then fit to a sigmoidal curve:

$R_{\mathrm{a}}\left(d_{\mathrm{p}}\right)=\frac{\operatorname{CCN}\left(d_{\mathrm{p}}\right)}{\operatorname{CN}\left(d_{\mathrm{p}}\right)}=\frac{E}{1+\left(\frac{d_{\mathrm{p} 50}}{d_{\mathrm{p}}}\right)^{C}}$

where $d_{\mathrm{p}}$ is the particle dry diameter, $E$ is the asymptote of $R_{\mathrm{a}}\left(d_{\mathrm{p}}\right)$ for large particle sizes, $d_{\mathrm{p} 50}$ is the characteristic dry diameter for which $50 \%$ of those particles act as CCN (and corresponds to the inflection point of the sigmoid) and $C$ is an empirical coefficient. Equation (1) describes the sizeresolved $\mathrm{CCN}$ data well (e.g., Fig. 3a); the fitted sigmoids upon integration also reproduce the measured $\mathrm{CCN}$ concentration to within $2.3 \%\left(R^{2}=0.98\right.$; not shown).

$R_{\mathrm{a}}\left(d_{\mathrm{p}}\right)$ can be used to study the size-dependent hygroscopicty and mixing state as follows. The function is evaluated at $20,30,40,50,60,70,80$ and $100 \mathrm{~nm}$ for all sigmoids obtained during a supersaturation cycle. The supersaturationdependant activation ratio function, $R_{\mathrm{a}}(S)$, (the fraction of particles of size $d_{\mathrm{p}}$ that are $\mathrm{CCN}$ at $S$ ), is thus determined and fit to a sigmoidal function:

$R_{\mathrm{a}}(S)=\frac{\operatorname{CCN}\left(S, d_{\mathrm{p}=\mathrm{const}}\right)}{\operatorname{CN}\left(d_{\mathrm{p}=\mathrm{const}}\right)}=\frac{E^{*}}{1+\left(S / S^{*}\right)^{C^{\prime}}}$

where $E^{*}$ is the asymptote of the sigmoid for large supersaturations, $S^{*}$ is the location of the inflection point and $C^{\prime}$ is a fitting constant. $E^{*}$ indicates the fraction of hygroscopic particles of size $d_{\mathrm{p}}, S^{*}$ indicates their "characteristic" (most probable) critical supersaturation, and, $C^{\prime}$ is related to the extent of their chemical heterogeneity. Figure $3 \mathrm{~b}$ presents typical examples of $R_{\mathrm{a}}(S)$, for 60 and $100 \mathrm{~nm}$ particles, obtained at 3 August, with the error bars representing the observed daily variability.

Equation (2) expresses the cumulative distribution function of critical supersaturations observed for particles of size $d_{\mathrm{p}}$. Assuming that this distribution arises solely from chemical heterogeneity of the particles (for a sheath-to-aerosol ratio of 10:1 used in this study, Lance (2007) showed this to be a very good assumption for values of $C^{\prime}>-10$, as the width of the DMA transfer function introduces relatively small dispersion), one can obtain a probability distribution of hygroscopicities as follows. From the definition of $\kappa$, one can express $S^{*}=\omega\left(\kappa^{*}\right)^{-1 / 2}$ and $S=\omega \kappa^{-1 / 2}$ where $\omega=$ $\left(\frac{4\left(\frac{4 M_{w} \sigma_{w}}{R T \rho_{w}}\right)^{3}}{27 d_{\mathrm{p}}^{3}}\right)^{1 / 2}$ and $\kappa^{*}$ is the characteristic (most probable) hygroscopicity of the distribution. Substitution into Eq. (2) 


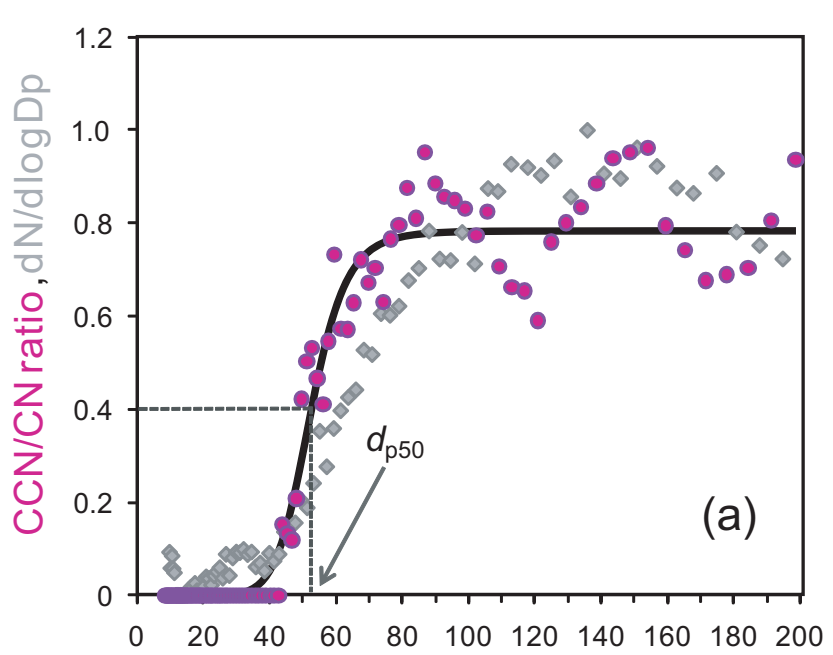

Dry Diameter $(\mathrm{nm})$

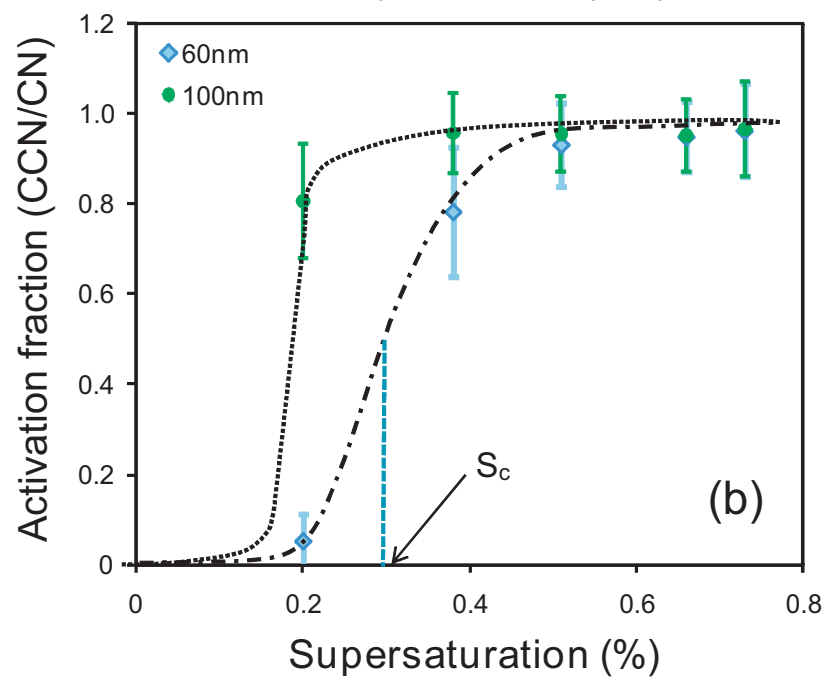

Fig. 3. (a) $\mathrm{CCN}$ activation fraction and distribution from 25 July at 11:49 a.m. (UTC + 2) with sigmoidal fit at $0.3 \%$ supersaturation and (b) example of CCN activity spectrum from 3 August (00:1211:58 a.m. $(\mathrm{UTC}+2)$ ) for 60 and $100 \mathrm{~nm}$ particles.

provides the hygroscopicity-dependant activation ratio function, $R_{\mathrm{a}}(\kappa)$, (the fraction of particles of size $d_{\mathrm{p}}$ that are CCN with hygroscopicity $\kappa)$,

$$
R_{\mathrm{a}}(\kappa)=\frac{\mathrm{CCN}\left(\kappa, d_{\mathrm{p}}=\mathrm{const}\right)}{\mathrm{CN}\left(\kappa, d_{\mathrm{p}}=\mathrm{const}\right)}=\frac{E^{*}}{1+\left(\kappa^{*} / \kappa\right)^{C^{\prime} / 2}}
$$

Differentiation and normalization of Eq. (3) provides the probability distribution function of $\kappa, p(\kappa)$, for particles of diameter $d_{\mathrm{p}}$ (Lance et al., 2007; Cerully et al., 2011),

$$
p(\kappa)=\frac{1}{E^{*}} \frac{d R_{\mathrm{a}}(\kappa)}{d \kappa}=\frac{C^{\prime}}{2} \frac{\left(\kappa^{*}\right)^{C^{*} / 2}}{\kappa^{\left(C^{*} / 2+1\right)}\left[1+\left(\frac{\kappa^{*}}{\kappa}\right)^{C^{*} / 2}\right]^{2}}
$$

from which one can compute the dispersion (standard deviation) of the hygroscopicity parameter around $\kappa^{*}$ as $\sigma_{\kappa}^{2}=$ $\frac{\int_{0}^{1}\left(\kappa-\kappa^{*}\right)^{2} p\left(\kappa^{\prime}\right) d \kappa^{\prime}}{\int_{0}^{1} p\left(\kappa^{\prime}\right) d \kappa^{\prime}}$ (Lance et al., 2007; Cerully et al., 2011). $\sigma_{\kappa}$ describes the "chemical dispersion" or the degree of chemical heterogeneity (i.e., mixing state) for the $\mathrm{CCN}$ of diameter $d_{\mathrm{p}}$. The upper limit of hygroscopicity in the integrals is set to unity (instead of $\infty$ ) to reflect the range of $\kappa$ found in the atmosphere (Cerully et al., 2011). Both $\sigma_{\kappa}$ and $\kappa^{*}$ are determined using the method discussed above for each diameter and supersaturation cycle $(\sim 30 \mathrm{~min})$.

\subsection{Activation kinetics}

$\mathrm{CCN}$ activation kinetics and changes thereof from the presence of organics can be determined from the droplet size of activated CCN measured at the OPC of the CFSTGC for all supersaturations considered. Most often, TDGA is applied to polydisperse $\mathrm{CCN}$, which exhibit a range of critical supersaturations and droplet sizes at the exit of the CFSTGC. If activation kinetics is as fast as for the pure salt, the droplet sizes observed in the OPC will thus be equal to (or larger) than the standard for the range of supersaturations measured (Sorooshian et al., 2008; Moore et al., 2008). If the sizes of the droplets formed on ambient aerosol are statistically smaller than the sizes of those formed on pure $\mathrm{NaCl}$ aerosol, then the presence of organics likely delay $\mathrm{CCN}$ activation. In this study, shifts in activation kinetics are detected by comparing the size of the activated ambient and $(\mathrm{NaCl}$ particles with (i) $S_{\mathrm{c}}$ equal to the instrument supersaturation, $S_{\mathrm{in}}$, (i.e., for particles with diameter $d_{\mathrm{p} 50}$ ), and, (ii) particles of $100 \mathrm{~nm}$ dry diameter (which tend to yield droplet sizes insensitive to their critical supersaturation; Ruehl et al., 2009).

\subsection{Ancillary measurements}

The chemical composition of the aerosol was determined by analysis of polytetrafluororoethylene (PTFE) $\left(\mathrm{PM}_{10}, \mathrm{PM}_{1.3}\right.$ and $\left.\mathrm{PM}_{1.3-10}\right)$ and quartz $\left(\mathrm{PM}_{1}\right.$ and $\left.\mathrm{PM}_{10}\right)$ daily and 4-h filter samples, respectively. PTFE and quartz filters were analyzed for water-soluble ions after extraction in ultrasonic bath with nanopure water. The solutions obtained were analyzed by ion chromatography (IC) for anions $\left(\mathrm{Cl}^{-}, \mathrm{Br}^{-}\right.$, $\left.\mathrm{NO}_{3}^{-}, \mathrm{SO}_{4}^{2-}, \mathrm{C}_{2} \mathrm{O}_{4}^{2-}\right)$ and cations $\left(\mathrm{K}^{+}, \mathrm{Na}^{+}, \mathrm{NH}_{4}^{+}, \mathrm{Mg}^{2+}\right.$, $\mathrm{Ca}^{2+}$ ), using the procedure of Bardouki et al. (2003). Quartz filters were also analyzed for organic and elemental carbon using the OC/EC analyzer (SUNSET Laboratory Inc.) and for water-soluble organic carbon (TOC- $\mathrm{V}_{\mathrm{CSH}}$, Total Organic Carbon Analyzer, SHIMATZU). Auxiliary chemical measurements $\left(\mathrm{O}_{3}, \mathrm{BC}\right)$ and meteorological parameters (wind speed and direction, pressure, temperature, relative humidity) were also continuously monitored. 


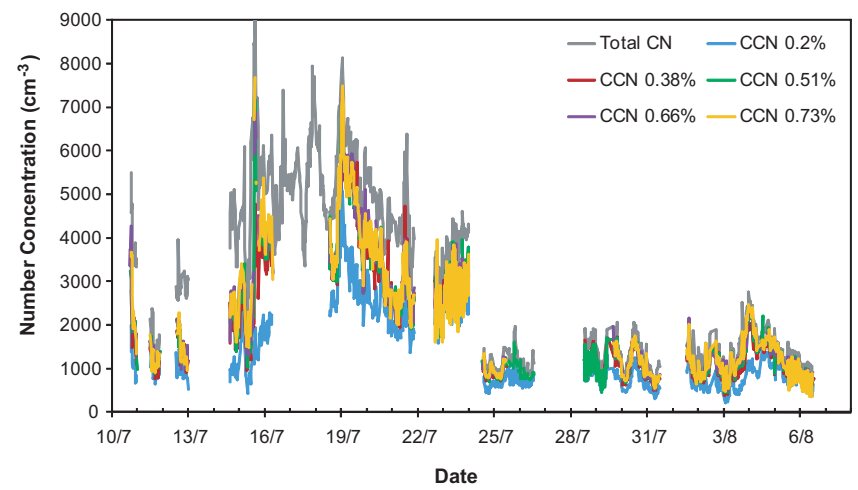

Fig. 4. Time series of the $\mathrm{CN}$ and $\mathrm{CCN}$ measurements throughout the measurement period.

\section{Results and discussion}

\subsection{CCN Measurements}

The complete time series of the $\mathrm{CN}$ and $\mathrm{CCN}$ measurements, obtained from the integration of the SMPS and CCN activity spectra can be seen in Fig. 4. The CCN generally correlate well with $\mathrm{CN}$, with $\mathrm{CCN}$ concentrations increasing (as expected) with supersaturation. Throughout the measurement period, $\mathrm{CCN}$ concentrations at each supersaturation level varied by up to a factor of 7 . The measured $\mathrm{CCN}$ concentrations at $0.51,0.66$ and $0.73 \%$ supersaturation were often very similar and close to $\mathrm{CN}$ concentrations (with average values of $2003 \pm 1304 \mathrm{~cm}^{-3}, 2205 \pm 1407 \mathrm{~cm}^{-3}$ and $2203 \pm 1432 \mathrm{~cm}^{-3}$, respectively). A two-sample t-test was performed on $\mathrm{CCN}$ timeseries observed at the highest supersaturations $(0.51,0.66 \%$, and $0.73 \%)$. It was found that the data at $0.51 \%$ supersaturation are statistically different (at the $95 \%$ confidence level) from those collected at 0.66 and $0.73 \%$. Data collected at the latter two levels however were statistically indistinguishable. The high activation fractions at these supersaturations $(0.8 \pm 1.0)$, and the small change between $0.5 \%$ and $0.75 \%$ suggests that most particles are activated at $\sim 0.6 \%$ supersaturation. This behavior is consistent with the findings of Bougiatioti et al. (2009) and reflects the characteristics of aged aerosol, where most particles are relatively large and contain significant amounts of soluble material.

$\mathrm{CCN}$ size distributions $\left(d \mathrm{CCN} / d \log D_{\mathrm{p}}\right)$ were calculated by multiplying $R_{\mathrm{a}}\left(d_{\mathrm{p}}\right)$ (Eq. 1$)$ with the corresponding aerosol particle number size distribution obtained from the SMPS (Moore et al., 2010). Examples of CCN size distributions at the different supersaturations are shown in Fig. 5. As the supersaturation increases, the $\mathrm{CCN}$ concentrations also increase with the distributions converging towards the aerosol total number distribution. At the lowest supersaturation $(0.2 \%)$, all particles with diameters above $90-120 \mathrm{~nm}$ activate, while all particles above $60 \mathrm{~nm}$ form droplets at $0.38 \%$.
Figure 6a shows campaign averages of $R_{\mathrm{a}}\left(d_{\mathrm{p}}\right)$ at different supersaturation levels. As expected, the diameter at which half of the particles activate $\left(d_{\mathrm{p} 50}\right)$, increases with decreasing supersaturation, although $R_{\mathrm{a}}\left(d_{\mathrm{p}}\right)$ is remarkably consistent throughout the measurement period. The CCN activity (portrayed by the relationship between $S_{\mathrm{c}}$ and $d_{\mathrm{p} 50}$ ) for the whole measurement period is presented in Fig. 6b. The horizontal error bars represent the variability in $d_{\mathrm{p} 50}$ throughout the study period; the variability reflects the shifts in aerosol mixing state and composition throughout the campaign. The vertical error bars denote the standard deviation of the instrument supersaturation between calibrations. The aerosol sampled throughout the measurement period is highly CCNactive even at the lower supersaturations. Figure $6 \mathrm{c}$ and $\mathrm{d}$ show $R_{\mathrm{a}}(S)$ for $40,50,60,80$ and $100 \mathrm{~nm}$ particles measured on 14 July and 24 July, respectively. The case of 24 July is chosen for being close to the campaign averages (within $15 \%$ ) and representative for the northeast and southeast sector. For air masses coming from Central and Eastern Europe (Fig. 6c) the activation fractions are somewhat lower and do not exceed $80 \%$, even at the higher supersaturations and larger particle sizes. This is not the case for local air masses (Greece) and masses originating from the rest of the geographic sectors (Fig. 6d), where the majority of the particle sizes $(\geq 50 \mathrm{~nm})$ are activated and form CCN $\left(R_{\mathrm{a}} \geq 0.8\right)$ even at $0.5 \%$ supersaturation. Despite these variations, the shape of the activation curves does not change significantly which implies that the size dependence of the particle composition does not vary much over time. It is possible that the lower $R_{\mathrm{a}}$ values observed for air masses coming from Central and Eastern Europe are due to external mixing with boundary layer aerosol and some less-hygroscopic material (e.g., soot). Indeed, for the time period of 14-24 July, BC average concentrations were in the order of $0.94 \pm 0.47 \mathrm{ng} \mathrm{m}^{-3}$ while for the rest of the measurement period (10-14 July and 25 July-6 August) average BC concentrations were of $0.67 \pm 0.24 \mathrm{ng} \mathrm{m}^{-3}$. The particle size distributions (Fig. 7) during that day (14 July) exhibited a bimodal profile, with a pronounced maxima in the small particle range $(40 \mathrm{~nm})$. Another possible explanation for the decrease in the $R_{\mathrm{a}}$ values is the mixing and subsequent dilution of the aerosol with "cleaner" air masses from aloft (Fig. 1a).

\subsection{Time series and chemical composition}

The complete time series of characteristic parameters derived from $R_{\mathrm{a}}(S)$ (e.g., $E^{*}, \kappa^{*}, \sigma_{\kappa}$ ) and the chemical composition measured throughout the campaign are illustrated in Fig. 8. The average particulate matter concentration of the $\mathrm{PM}_{1}$ fraction during the measurement period was of $13.75 \pm 4.8 \mu \mathrm{g} \mathrm{m}^{-3}$, accounting for $40 \pm 9.5 \%$ of the total mass. Ammonium sulfate accounted for $89.9 \pm 4.2 \%$ of the total inorganic $\mathrm{PM}_{1}$ mass fraction, with the remaining inorganic mass consists mostly of $\mathrm{K}^{+}$, and on occasion, small amounts of $\mathrm{NO}_{3}^{-}$and $\mathrm{Cl}^{-}$. The sulfate volume fraction on 

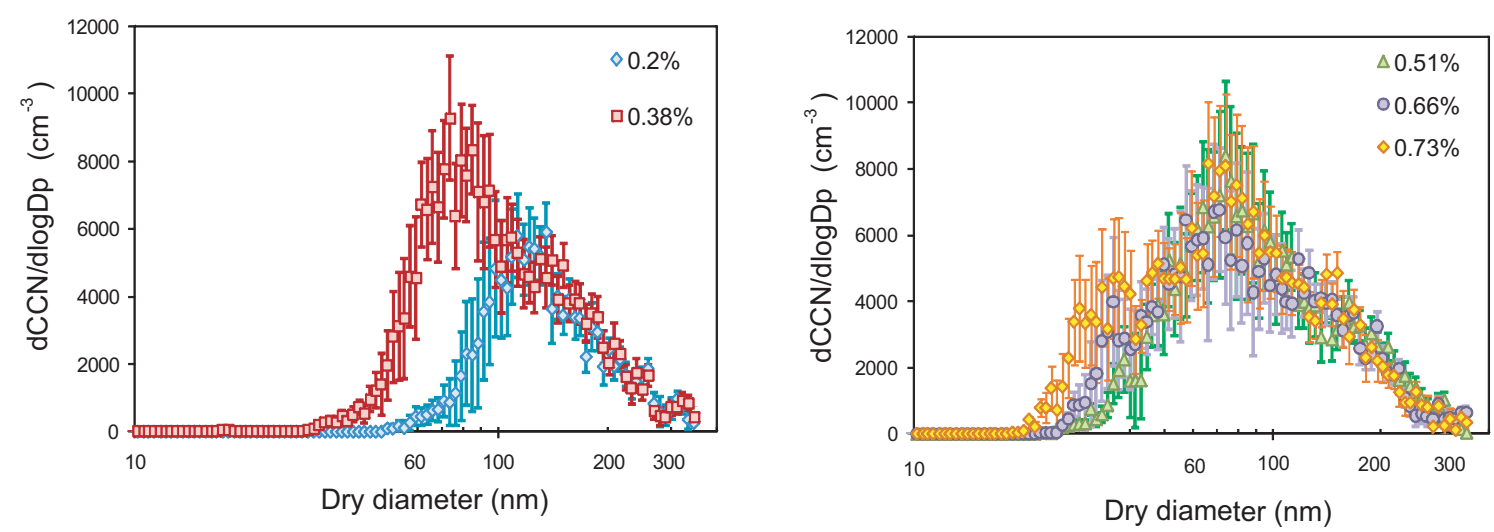

Fig. 5. Examples of daily average CCN distributions from 2 August at different levels of supersaturation.

Table 1. Average concentrations for organic components and major ions for $\mathrm{PM}_{1}$ and $\mathrm{PM}_{10}$.

\begin{tabular}{lrr|rr}
\hline & \multicolumn{2}{c|}{$\mathrm{PM}_{1}$} & \multicolumn{2}{c}{$\mathrm{PM}_{10}$} \\
\cline { 2 - 5 } $\begin{array}{l}\text { Concentration } \\
\left(\mu \mathrm{g} \mathrm{m}^{-3}\right)\end{array}$ & $10-23$ July & 24 July-6 August & 10-23 July & 24 July-6 August \\
\hline $\mathrm{OC}$ & $2.58 \pm 1.12$ & $3.04 \pm 1.55$ & $3.16 \pm 1.48$ & $3.72 \pm 1.69$ \\
$\mathrm{EC}$ & $0.36 \pm 0.25$ & $0.32 \pm 0.17$ & $0.39 \pm 0.19$ & $0.4 \pm 0.22$ \\
$\mathrm{WSOC}$ & $1.74 \pm 0.86$ & $1.93 \pm 0.84$ & $1.55 \pm 0.62$ & $1.61 \pm 0.99$ \\
$\mathrm{SO}_{4}^{2-}$ & $7.01 \pm 2.4$ & $5.53 \pm 1.69$ & $8.36 \pm 1.37$ & $6.98 \pm 1.01$ \\
$\mathrm{NO}_{3}^{-}$ & $0.17 \pm 0.12$ & $0.06 \pm 0.04$ & $2.53 \pm 0.14$ & $2.56 \pm 0.09$ \\
$\mathrm{Cl}^{-}$ & $0.35 \pm 0.23$ & $0.05 \pm 0.04$ & $2.73 \pm 0.95$ & $1.47 \pm 0.58$ \\
$\mathrm{~K}^{+}$ & $0.47 \pm 0.28$ & $0.24 \pm 0.11$ & $0.69 \pm 0.18$ & $0.34 \pm 0.07$ \\
$\mathrm{Na}^{+}$ & $0.03 \pm 0.01$ & $0.03 \pm 0.02$ & $0.48 \pm 0.33$ & $1.47 \pm 0.4$ \\
$\mathrm{NH}_{4}^{+}$ & $2.12 \pm 0.61$ & $1.8 \pm 0.5$ & $2.32 \pm 0.33$ & $2.08 \pm 0.3$ \\
$\mathrm{Ca}^{2+}$ & $0.3 \pm 0.23$ & $0.02 \pm 0.02$ & $1.12 \pm 0.31$ & $0.97 \pm 0.45$ \\
\hline
\end{tabular}

average was $0.3 \pm 0.06$ (Fig. $8 \mathrm{~b}$ ) and the sulfate concentration had a campaign average of $6.6 \pm 2.8 \mu \mathrm{g} \mathrm{m}^{-3}$. As expected, air masses originating from Central-Eastern Europe presented a higher particle load, which is expected for anthropogenic emission-laden air masses, but with a smaller amount of sulfate $\left(5.3 \pm 1.6 \mu \mathrm{g} \mathrm{m}^{-3}\right)$ and therefore this can explain the lower hygroscopicity values observed during that period. These air masses usually contain a larger number of small particles that demonstrate larger activation diameters, lower activation fractions, as well as lower hygroscopicity. The particulate organic matter (OM) concentrations remained close to the mean value of $6 \pm 2.7 \mu \mathrm{g} \mathrm{m}^{-3}$, nevertheless it is expected that the $\mathrm{CCN}$ activity is influenced by the nature of these organics ("fresh" vs. "aged"). From the organic carbon analysis, the fine mode $\left(\mathrm{PM}_{1}\right)$ represented $72.3 \pm 17.7 \%$ of the total organic carbon concentration, varying from 1.1 to $6.1 \mu \mathrm{g} \mathrm{m}^{-3}$. The WSOC analysis showed that $51.6 \pm 7.6 \%$ of the total (bulk) organic carbon was water-soluble, with this ratio reaching $67.1 \pm 6.6 \%$ in the fine fraction. Although high, this ratio is consistent with the aged nature of the aerosol (Jaffrezo et al., 2005 and references within) and is consistent with $\mathrm{PM}_{1}$ WSOC reported for the area (Bougiatioti et al., 2009). The carbon components and major ion average concentrations for $\mathrm{PM}_{1}$ and $\mathrm{PM}_{10}$ are presented in Table 1.

The effective hygroscopicity parameter (Fig. 8a) derived from the $\mathrm{PM}_{10}$ filter analysis was $0.22 \pm 0.04$, which is in similar to $\kappa(0.24 \pm 0.08)$ derived from $\mathrm{PM}_{10}$ measurements at the same location but over a different time period (Bougiatioti et al., 2009). $\kappa$ is calculated from the soluble fractions of the organics and the sulfate $\left(\kappa=\kappa_{\mathrm{S}} \varepsilon_{\mathrm{S}}+\kappa_{\mathrm{org}} \varepsilon_{\mathrm{org}}\right)$, with $\kappa_{\mathrm{s}}=0.6$ and $\kappa_{\text {org }}=0.16$ (Bougiatioti et al., 2009). From the SMCA analysis, we can derive a size-distribution average hygroscopicity parameter, $\bar{\kappa}$,

$$
\bar{\kappa}=\frac{\int_{0}^{\infty} \kappa\left(d_{\mathrm{p}}\right) n\left(d_{\mathrm{p}}\right) d d_{\mathrm{p}}}{\int_{0}^{\infty} n\left(d_{\mathrm{p}}\right) d d_{\mathrm{p}}}
$$



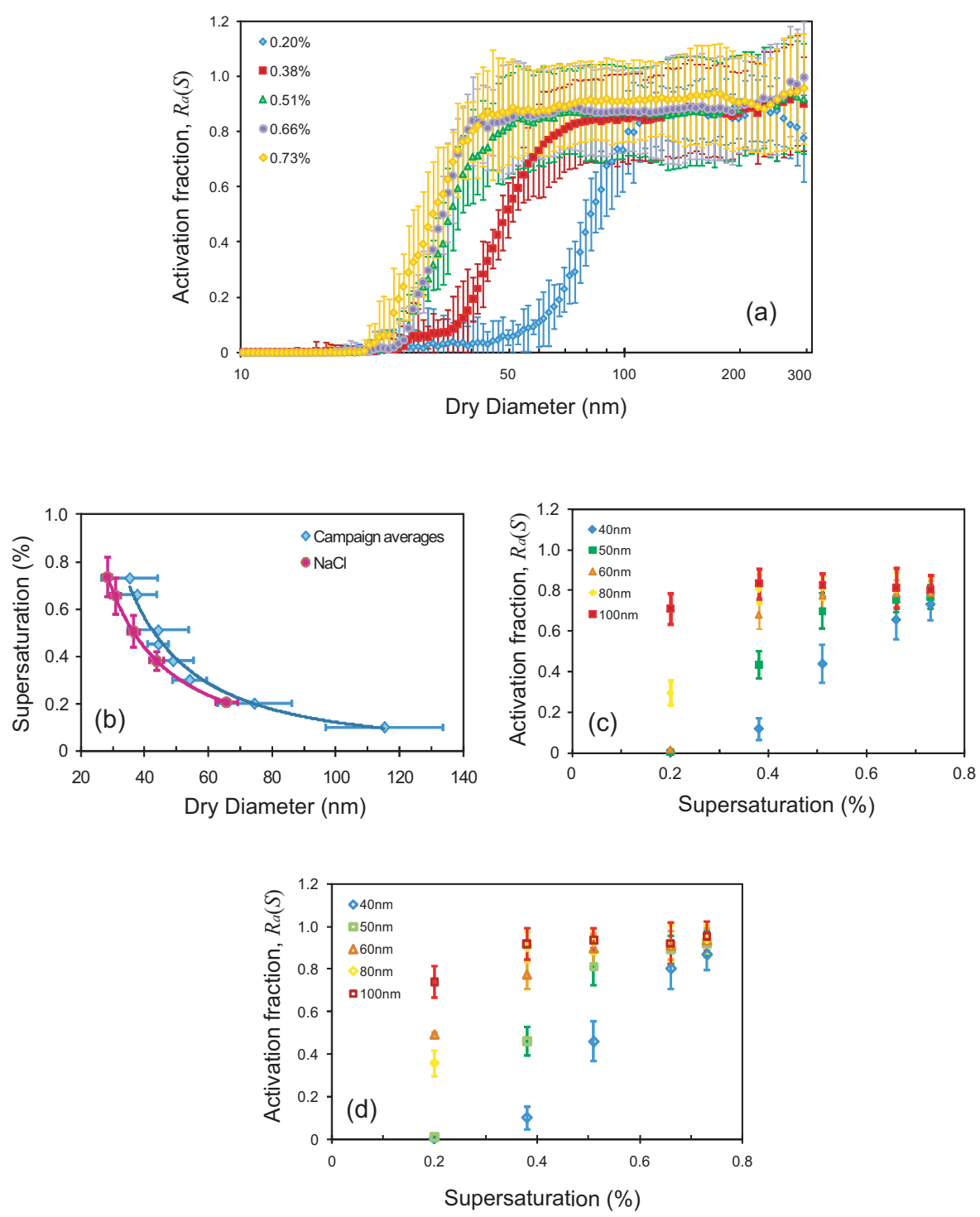

Fig. 6. (a) Averaged size-resolved CCN efficiency spectra at different levels of supersaturation $(0.2-0.73 \%)$ : activated particle fraction plotted against particle dry diameter, (b) CCN activation spectrum $\left(S_{\mathrm{c}}\right.$ vs. $\left.d_{\mathrm{p} 50}\right)$ for the whole measurement period, (c) $R_{\mathrm{a}}(S)$ for $14 \mathrm{July}$, and, (d) $R_{\mathrm{a}}(S)$ for 24 July.

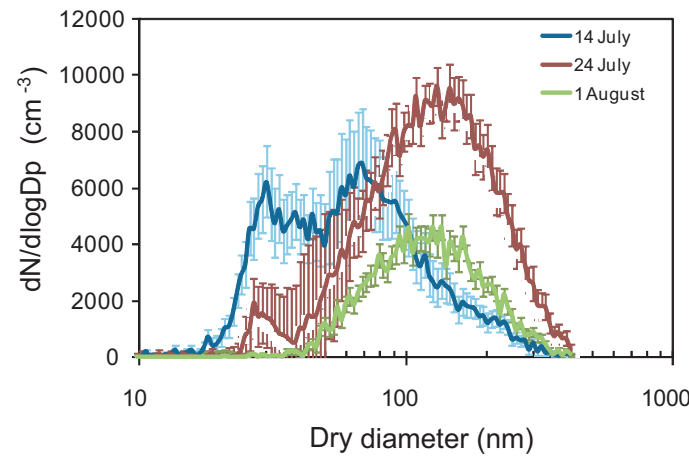

Fig. 7. Daily average aerosol size distributions, characteristic of the air masses sampled. where $n\left(d_{\mathrm{p}}\right)$ is the aerosol number size distribution function (obtained from the SMPS observations). The average $\bar{\kappa}$ over the measurement period was $0.34 \pm 0.04$, and is somewhat higher than the $\kappa$ derived from the $\mathrm{PM}_{10}$-filter measurements but closer to the $\kappa$ derived from the daily $\mathrm{PM}_{1}$ filters $(0.31 \pm 0.06)$, suggesting an on average higher hygroscopicity of small particles (which would affect $\bar{\kappa}$ more than the mass-weighted $\kappa$ ). Nevertheless, both hygroscopicity parameters are not considerably different and close to the average value of 0.3 proposed for continental locations (Andreae and Rosenfeld, 2008; Pöschl et al., 2008; Rose et al., 2008).

Figure 8c shows campaign-average values of $E^{*}, \kappa^{*}$ and $\sigma_{\kappa}$ deduced from $R_{\mathrm{a}}(S)$; Fig. 8d, e present the same quantities for 14 and 24 July, respectively. As expected, all particles are highly hygroscopic throughout the measurement 

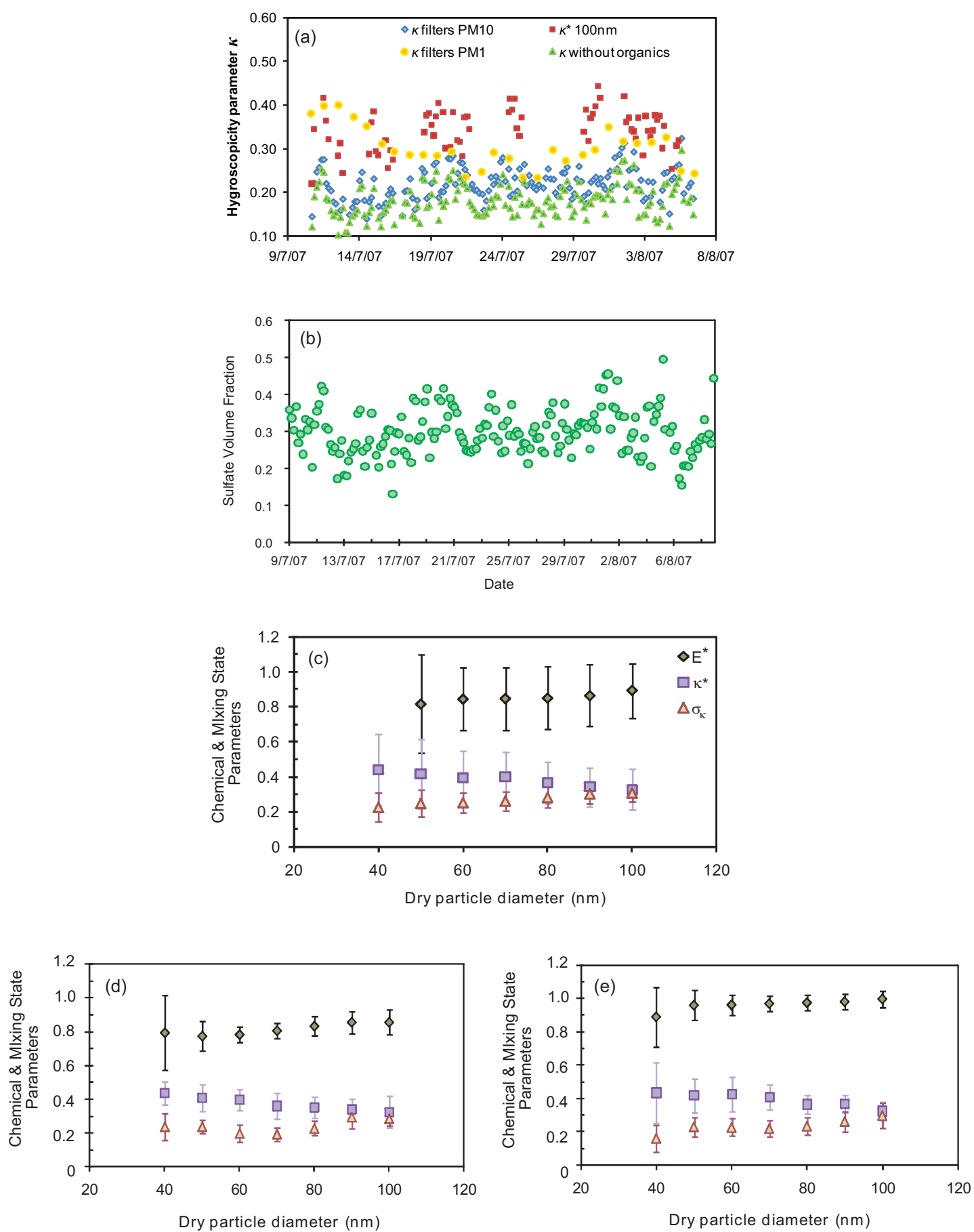

Fig. 8. (a) Time series of the characteristic (SMCA, $100 \mathrm{~nm}$ diameter) and filter-derived hygroscopicity parameter for the totality of the measurement period, (b) sulfate volume fraction time series and (c) chemical and mixing state parameters $\left(E^{*}, \kappa^{*}, \sigma_{\kappa}\right)$ averages for the whole measurement period and for 14 July (d) and 24 July (e).

period. Larger particles exhibit somewhat larger $E^{*}$ (reflective of their age, or complete activation at the maximum supersaturation measured) and lower $\kappa^{*}$. The latter is consistent with more sulfate condensation on the smaller particles, and confirms the postulation of Bougiatioti et al. (2009) on size-dependant hygroscopicity. The chemical dispersion, portrayed by $\sigma_{\kappa}$, represents the standard deviation of the fit around $\kappa^{*}$. It remains low and mostly constant throughout the whole measurement period for all particle sizes, consistent with the aged and well-mixed nature of the 

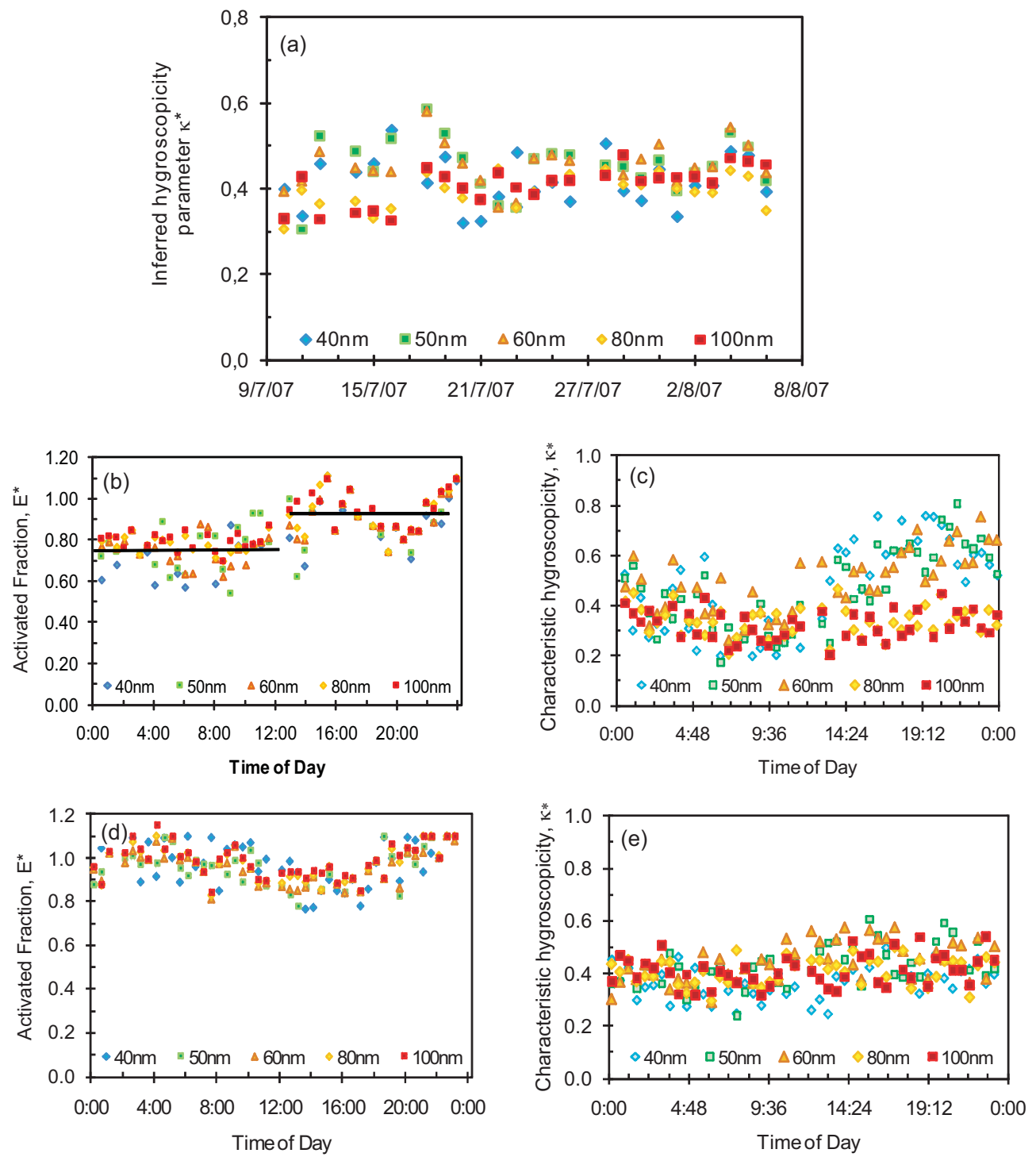

Fig. 9. (a) Time series of the hygroscopicity parameter $\kappa^{*}$ for the five dry particle sizes, (b) diurnal variability of the activated fraction $\left(E^{*}\right)$ for 14-15 July, (c) inferred hygroscopicity parameter $\left(\kappa^{*}\right)$ for 14-15 July, (d) $E^{*}$ for 30-31 July, and (e) $\kappa^{*}$ for 30-31 July, respectively.

aerosol arriving at Finokalia. Comparing the characteristics of aerosol in different air masses, Central-Eastern European aerosol (Fig. 8d) exhibits $2.5 \%$ smaller hygroscopicity parameter than particles from Greece and eastern/southern sector (Fig. 8e). The main difference was a small decrease in the $E^{*}$ values, to around 0.85 . This decrease may suggest that the particles exhibit a small (but detectable) chemical heterogeneity which leads to a small fraction of them not activating in the CFSTGC.

\subsection{Diurnal behavior of $\mathrm{CCN}$ activity}

The complete time series of the inferred hygroscopicity parameter $\kappa^{*}$ given as daily averages, for five of the dry particle sizes examined $(40,50,60,80$ and $100 \mathrm{~nm})$, is plotted in
Fig. 9a. We can see that the day-to-day variability of $\kappa^{*}$ is less pronounced as we shift to larger dry particle sizes, with the smaller particles exhibiting greater hygroscopicity values $(\sim 0.1 \kappa$ units higher) and variability than the larger ones. The greater variability for smaller particles can partially reflect their origin, as they tend to be less aged (hence more heterogeneous in their properties) than accumulation mode particles. After 20 July, the day-to-day variability within the dry particle sizes decreases, even at the smallest sizes. This is probably due to the fact that after 20 July the air masses arriving at the site originated mainly from the "nonpolluted" areas, such as the Western Mediterranean, Eastern and Southern sector, as well as local Northern sector (Greece mainland, Southern France and Southern Italy). Therefore 


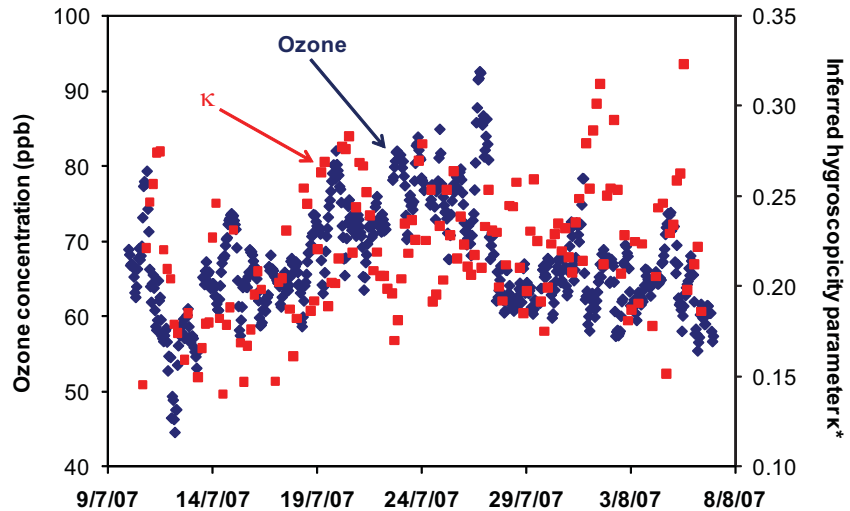

Fig. 10. Time series of $\kappa^{*}$ versus ozone concentration.

in the absence of "fresh" anthropogenic emission-laden air masses, aerosol chemical composition (hence hygroscopicity) is more uniform.

Having in mind that the smallest activation fractions were found for air masses arriving from Central-Eastern Europe at the beginning of the measurement campaign, we examined the diurnal variability of the activated fraction as well as the hygroscopicity for the five dry particle sizes, for 14-15 July and for 30-31 July (which lies within the more "uniform" period). The results are presented in Fig. 9b, c, d and e. It can be seen that $E^{*}$ increases after $14 \mathrm{~h}$ local time, for all particle sizes considered, with the average values before, and after $14 \mathrm{~h}$ being $0.76 \pm 0.09$ and $0.93 \pm 0.1$, respectively. $\kappa^{*}$ also increases after $14 \mathrm{~h}$, but mostly for particles smaller than $80 \mathrm{~nm}$ diameter. Photochemical oxidation of gas phase chemical species and subsequent condensation of low volatility products is a plausible explanation, as when e.g. SOA or sulfate condenses upon externally-mixed unactivated particles, it may shift these particles into the CCN active spectrum, with a corresponding increase in $E^{*}, \kappa^{*}$. The connection between photochemical oxidation and CCN activity is corroborated by the similar trends between $\kappa^{*}$ and $\mathrm{O}_{3}$ concentrations which tend to follow each other (Fig. 10). Furthermore, photochemical oxidation in the particle phase may add functional groups to the organic constituents already present, making them more hygroscopic. This is consistent with the conclusions of Hildebrandt et al. (2010), who showed that the OA composition exhibits a statistically significant diurnal variation with more oxidized OA present in the afternoon (although there was no statistically significant diurnal variation observed in the bulk composition of the non-refractory submicron aerosol). The same trend is observed in the CCN activity (with an increase in $\kappa^{*}$ values after $14 \mathrm{~h}$ ) but is less pronounced (Fig. 9). Finally, $E^{*}$ on 30-31 July shows a slight decrease (by $8 \%$ ) around $14 \mathrm{~h}$ local time, which may be caused by the mixing and dilution of the aerosol with air masses from aloft (Fig. 1d). A twosample t-test for unequal differences suggests this decrease is statistically significant at the $95 \%$ confidence level.

\subsection{CCN closure}

A closure study for the prediction of $\mathrm{CCN}$ concentrations is performed using different assumptions about the hygroscopic behavior of OM. The CCN concentration in each SMCA scan was calculated by integrating the $\mathrm{CCN}$ size distribution, $R_{\mathrm{a}}\left(d_{\mathrm{p}}\right) n\left(d_{\mathrm{p}}\right)$,

$\mathrm{CCN}=\int_{0}^{\infty} R_{\mathrm{a}}\left(d_{\mathrm{p}}\right) n\left(d_{\mathrm{p}}\right) d d_{\mathrm{p}}$

The calculated $\mathrm{CCN}$ are then compared against predictions using $\kappa$-Köhler theory assuming a hygroscopicity parameter $\kappa=\kappa_{\mathrm{S}} \varepsilon_{\mathrm{S}}+\kappa_{\mathrm{o}} \varepsilon_{\mathrm{o}}$, where $\kappa_{\mathrm{S}}, \kappa_{\mathrm{o}}$, is the hygroscopicity of the salt and organic fractions, respectively, and $\varepsilon_{\mathrm{s}}, \varepsilon_{\mathrm{o}}$ their respective volume fraction in the dry aerosol. Three closure approaches are investigated: (a) assuming that the organic fraction is insoluble, i.e. $\kappa_{\mathrm{o}}=0$, (b) $70 \%$ of the organics are water-soluble (as suggested by a carbon mass balance of extracted filters; Bougiatioti et al., 2009) and using the respective (variable) hygroscopicity parameter resulting from the 4-h filter analysis and, (c) using a prescribed CCN hygroscopicity parameter value of $\kappa=0.34$, which is the average value for all investigated particle sizes over the whole measurement period.

Table 2 presents the predicted against measured $\mathrm{CCN}$ for the whole measurement period, assuming that the organics are insoluble. Even with this simplified treatment, the CCN closure is very good (relative error $-2.8 \pm 14 \%, R^{2}=0.93$ ) for the whole dataset. When the average organic watersoluble fraction is considered in the $\mathrm{CCN}$ calculations, the closure error is further reduced $(+1.8 \pm 12 \%)$ and the underprediction bias and scatter is diminished (best fit slope 0.97, $R^{2}=0.95$ ). The underprediction bias at the low supersaturations is also reduced at the higher supersaturations (Table 2). Using the time-dependant WSOC/OC ratio does not substantially affect the closure, as it changes $\mathrm{CCN}$ predictions by only $1 \%$ (not shown).

Table 2 also shows the predicted against measured CCN using a hygroscopicity parameter value of $\kappa=0.34$. For this case also the closure is very good (relative error $2.6 \pm 22 \%$, $R^{2}=0.92$ ). The scatter is almost twofold higher than the two cases examined above, reflective of the unresolved variability in $\kappa$, especially during the high-concentration periods (Fig. 9). Overall, the changes in the predicted $\kappa$ between the three calculation scenarios do not affect closure considerably, largely because of the generally large $\mathrm{CCN}$ activation fraction and homogeneity of the aged aerosol population.

\subsection{Droplet activation kinetics}

Figure 11a shows the application of TDGA to the droplet growth data for the whole measurement period, for large aerosol particles $(100 \mathrm{~nm})$ while Fig. $11 \mathrm{~b}$ shows the droplet sizes for CCN with $S_{\mathrm{c}}$ equal to the instrument supersaturation, $S_{\text {in }}$ (i.e., for particles with diameter $d_{\mathrm{p} 50}$ ). The solid line 
Table 2. Regression statistics for the CCN closure.

\begin{tabular}{crr|rr|rr}
\hline \multirow{2}{*}{$\begin{array}{c}\text { Supersaturation (\%) } \\
\text { (number of data points) }\end{array}$} & \multicolumn{2}{c|}{ WSOC/OC $=0$} & \multicolumn{2}{c|}{ WSOC/OC $=0.7$} & \multicolumn{2}{c}{$\kappa=0.34$} \\
\cline { 2 - 6 } & $\begin{array}{c}\mathrm{CCN}_{\text {predicted }} \\
\mathrm{CCN}_{\text {observed }}\end{array}$ & $R^{2}$ & $\frac{\mathrm{CCN}_{\text {predicted }}}{\mathrm{CCN}_{\text {observed }}}$ & $R^{2}$ & $\overline{\mathrm{CN}}_{\text {predicted }}$ & $R^{2}$ \\
\hline $0.21(1012)$ & 0.94 & 0.94 & 1.02 & 0.95 & 0.97 & 0.86 \\
$0.38(865)$ & 0.92 & 0.93 & 0.99 & 0.96 & 0.92 & 0.92 \\
$0.52(942)$ & 0.98 & 0.95 & 1.00 & 0.96 & 0.93 & 0.93 \\
$0.66(816)$ & 0.97 & 0.94 & 0.99 & 0.94 & 0.92 & 0.92 \\
$0.73(762)$ & 0.94 & 0.92 & 0.96 & 0.93 & 0.94 & 0.89 \\
\hline
\end{tabular}
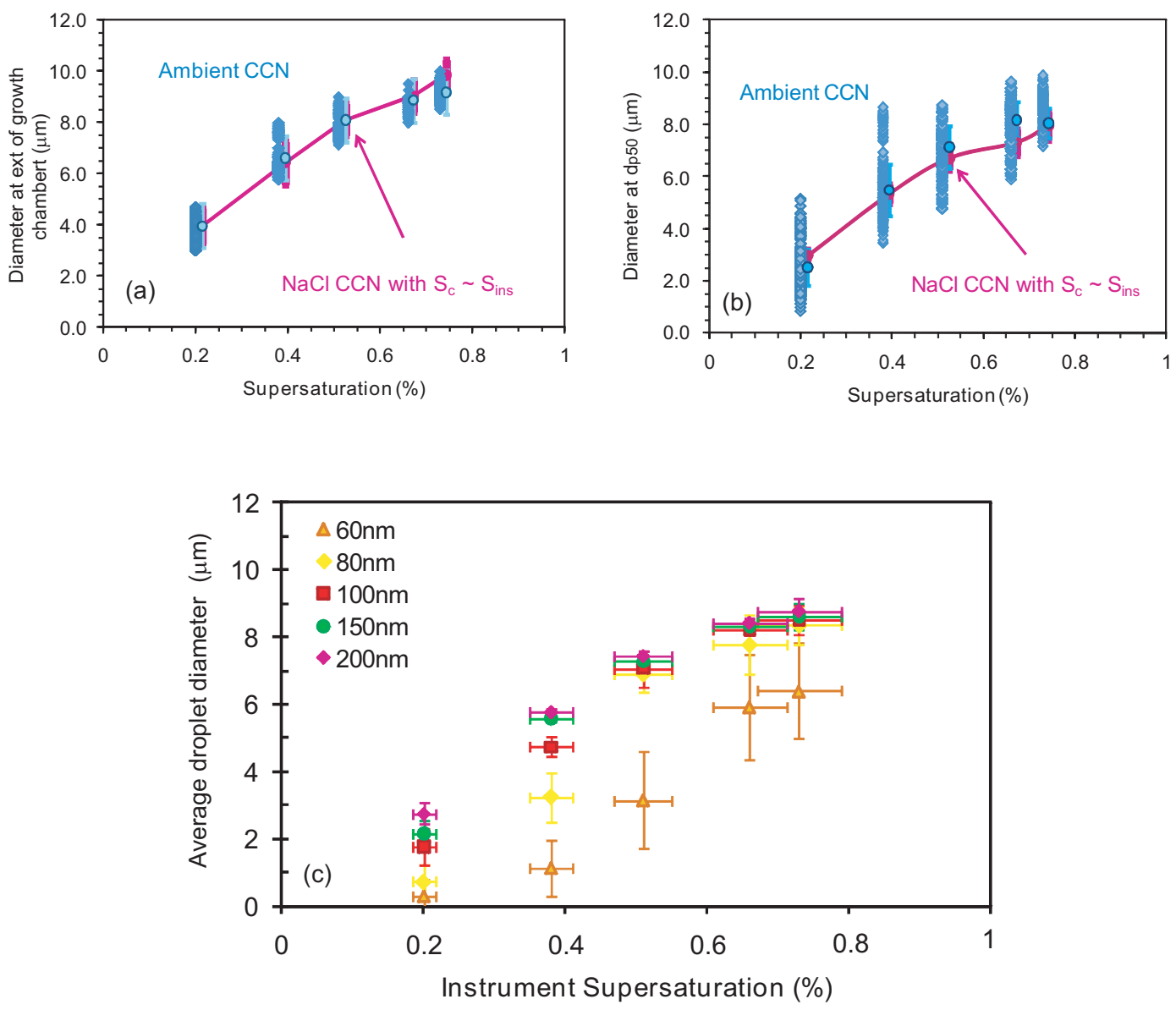

Fig. 11. (a) Droplet sizes of $\mathrm{CCN}$ at the different supersaturations for ambient and calibration aerosol for large particles (100 nm) (b) Droplet sizes of ambient $\mathrm{CCN}$ at $d_{\mathrm{p} 50}$ and (c) Average droplet diameter at different dry particle sizes, all as measured at the exit of the growth chamber.

represents the size of the activated calibration $\mathrm{NaCl}$ particles (with $S_{\mathrm{c}}$ equal to the instrument supersaturation), while the light-colored round points represent the average droplet size from the ambient aerosol activation data with the respective standard deviation. For large aerosol the droplet diameter from ambient measurements is on average above the lower limit established by the calibration aerosol. The percentile of droplets smaller than the lower limit of the $\mathrm{NaCl}$ ones is $\sim 7.5 \%$ at the lower supersaturations and does not exceed $12.5 \%$ at the higher supersaturations. The variability in the droplet size seen in the $\mathrm{NaCl}$ and ambient aerosol data is of the same order as the OPC bin resolution $(0.5 \mu \mathrm{m})$.

The droplet sizes from $d_{\mathrm{p} 50}$ particles exhibits larger scatter than for $100 \mathrm{~nm}$ aerosol (Fig. 11b). This can also be seen in Table 3, which summarizes the average values of droplet sizes for both cases. The difference $(\sim 67 \%)$ between the 
Table 3. Average droplet size (standard deviation) measured by the optical particle counter $(\mu \mathrm{m})$ for different supersaturations. Results shown for Finokalia and $\mathrm{NaCl}$ calibration aerosol with dry particle diameter of size $d_{\mathrm{p} 50}$ and $100 \mathrm{~nm}$.

\begin{tabular}{ccc|cc}
\hline \multirow{2}{*}{$\begin{array}{c}\text { Supersaturation } \\
(\%)\end{array}$} & \multicolumn{2}{c|}{ Dry diameter $d_{\mathrm{p} 50}$} & \multicolumn{2}{c}{ Dry diameter $100 \mathrm{~nm}$} \\
\cline { 2 - 5 } & Finokalia & $\mathrm{NaCl}$ & Finokalia & $\mathrm{NaCl}$ \\
\hline 0.21 & $2.2(0.6)$ & $3.0(0.6)$ & $3.7(0.3)$ & $4.0(0.7)$ \\
0.38 & $4.9(0.6)$ & $5.4(0.7)$ & $6.4(0.3)$ & $6.4(0.8)$ \\
0.52 & $6.8(0.6)$ & $6.7(0.6)$ & $7.9(0.3)$ & $8.1(0.6)$ \\
0.66 & $7.9(0.6)$ & $7.5(0.6)$ & $8.7(0.4)$ & $9.0(0.6)$ \\
0.73 & $8.1(0.6)$ & $8.0(0.6)$ & $9.3(0.3)$ & $9.9(0.6)$ \\
\hline
\end{tabular}

two average values $(2.21$ vs. $3.68 \mu \mathrm{m})$ at the lowest supersaturation diminishes as the latter increases $(\sim 14 \%$ at the highest supersaturation). This is consistent with growth via water vapor condensation, which tends to narrow the droplet distribution as the supersaturation (and exposure time) increases. Activated CCN with $S_{\mathrm{c}} \sim S_{\text {in }}$ occasionally yields droplets that are smaller than those from calibration $\mathrm{NaCl}$ particles. Given that $R_{\mathrm{a}}\left(d_{\mathrm{p}}\right)$ is steepest at $d_{\mathrm{p} 50}$, small fluctuations in the instrument conditions, the presence of some multiply-charged particles and the finite width of the DMA transfer function may broaden the distribution of ambient activated droplets beyond what was seen in the $\mathrm{NaCl}$ calibrations. Nevertheless, the percentile of droplets smaller than the ones formed from $\mathrm{NaCl}$ does not exceed $6.5 \%$ (of the total number) for the higher supersaturations and is $\sim 7.8 \%$ for the lower supersaturations. These occurances are not correlated with airmasses; it is therefore unclear if the observed scatter in the droplet values is associated with experimental uncertainty rather than a kinetic limitation caused by the presence of the organics in the aerosol sampled.

Finally, in Fig. 11c we plot the average droplet diameter as a function of the $\mathrm{CCNc}$ instrument supersaturation for 5 different dry particle sizes. The vertical error bars represent the variability in the average droplet diameter throughout the study period, calculated separately for each supersaturation and each dry particle diameter. The horizontal error bars represent the maximum supersaturation uncertainty $(8 \%)$ quoted for the instrument (Rose et al., 2007). The droplet growth is slightly greater for larger dry particle diameters (Table 3); this is because their critical supersaturation is lower than for small particles hence grow for a longer time period during their residence in the CCNc. As the dry particle sizes augments however, the activated droplet diameter values converge, especially at the higher supersaturations. This is consistent with droplets approaching the asymptotic limit of diffusional growth, $D_{\mathrm{p}} \rightarrow 2 G \tau S_{\text {in }}$, where $\tau$ is the exposure time of the CCN to supersaturation $S_{\text {in }}$, and, $G$ is the water vapor mass transfer coefficient to the droplet (Nenes et al., 2001b). The convergence to a common limit for all ambient particles suggests that the mass transfer coefficient is the same for all particles, and implies that shifts in activation kinetics (which would manifest as changes in $G$ ) are not considerable enough to affect the observed droplet size.

Based on the above it can be concluded that for the range of supersaturations considered, the aged organics present in the Eastern Mediterranean aerosol do not significantly delay the CCN activation and growth process. This is consistent with the abundant amounts of sulfate and highly oxidized organics (the extent of which is expressed by the high ratio WSOC/OC) present in the aerosol, which tends to be associated with rapid activation kinetics (Padró et al., 2010; Engelhart et al., 2008, 2011; Asa-Awuku et al., 2009, 2010; Cerully et al., 2011). Although kinetic delays have been previously observed in aerosol with anthropogenic influence (Chang et al., 2007; Sorooshian et al., 2008; Murphy et al., 2009; Ruehl et al., 2009; Mochida et al., 2010; Asa-Awuku et al., 2011), this effect was not seen at Finokalia. This may be a consequence of the highly aged (oxidized) nature of the aerosol combined with its preconditioning (wetting) in the marine boundary layer prior to sampling.

\section{Summary and conclusions}

Size-resolved CCN measurements from 0.21 to $0.73 \%$ supersaturation, aerosol size distribution and chemical composition were carried out at the Finokalia measuring site of the University of Crete during the FAME07 campaign in summer 2007. The sampled aerosols arrived at the site after longrange transport with the organic fraction being mainly secondary, "aged" and highly oxidized. The majority of the particles tend to activate at a supersaturation of $0.6 \%$. When air masses originated from Central-Eastern Europe, aerosol particle concentrations were higher and a statistically-significant lower hygroscopicity parameter value was observed. The hygroscopicity of small particles $(40 \mathrm{~nm})$ is $0.1 \kappa$ units higher than the one of larger particles $(100 \mathrm{~nm})$ with all particles being highly hygroscopic. Particles smaller than $80 \mathrm{~nm}$ exhibit higher hygroscopicity values after $14 \mathrm{~h}$ local time, which is consistent with the condensation of secondary aerosol and oxidation of organic constituents in the particle phase.

Application of Köhler theory using measurements of bulk composition and size distribution resulted in excellent $\mathrm{CCN}$ closure. Assuming that organics are insoluble, closure was attained to within $2.8 \pm 14 \%$ for all supersaturations and with including the effects of the water-soluble organic fraction reduces the underprediction bias (to $1.8 \pm 12 \%$ ) and the scatter (from $R^{2}=0.93$ to 0.95 ). This level of closure is consistent with the measurements carried out at Finokalia by Bougiatioti et al. (2009). Our results show a relatively lower error in closure than studies with aerosol with a variety of distinct local sources (e.g., Medina et al., 2007; Gunthe et al., 2009; Lance et al., 2009; Asa-Awuku et al., 2011), which tend to overestimate $\mathrm{CCN}$ concentrations (especially under 
polluted conditions). Finally, analysis of the droplet sizes using asymptotic and threshold droplet growth analysis suggests that the activation kinetics of ambient $\mathrm{CCN}$ is mostly similar to $\mathrm{NaCl}$ calibration aerosol. This finding is consistent with evidence to date that highly oxidized aerosol grows as quickly as calibration salt aerosol. The present study results suggests that, in the case of hygroscopic aerosols, in areas not influenced by local sources, CCN activity and droplet activation kinetics can be successfully parameterized and predicted, even when size-resolved chemical composition measurements are not available.

Acknowledgements. This research project (PENED) is co-financed by E.U.-European Social Fund (75\%) and the Greek Ministry of Development-GSRT $(25 \%)$. This research was also supported by the FP7 Integrated Project PEGASOS (contract number 265148). A. Nenes acknowledges support from the US NSF (CAREER) and from NOAA-ACC. S. N. Pandis acknowledges support by NSF-ATM 0732598.

Edited by: V.-M. Kerminen

\section{References}

Andreae, M. O. and Rosenfeld, D.: Aerosol-cloud-precipitation interactions. Part 1. The nature and sources of cloud-active aerosols, Earth Sci. Rev., 89, 13-41, 2008.

Asa-Awuku, A., Nenes, A., Sullivan, A. P., Hennigan, C. J., and Weber, R. J.: Investigation of molar volume and surfactant characteristics of water-soluble organic compounds in biomass burning aerosol, Atmos. Chem. Phys., 8, 799-812, doi:10.5194/acp8-799-2008, 2008.

Asa-Awuku, A., Engelhart, G. J., Lee, B. H., Pandis, S. N., and Nenes, A.: Relating CCN activity, volatility, and droplet growth kinetics of $\beta$-caryophyllene secondary organic aerosol, Atmos. Chem. Phys., 9, 795- 812, doi:10.5194/acp-9-795-2009, 2009.

Asa-Awuku, A., Moore, R. H., Nenes, A., Bahreini, R., Holloway, J. S., Brock, C. A., Middlebrook, A. M., Ryerson, T., Jimenez, J., DeCarlo, P., Hecobian, A., Weber, R. Stickel, R., Tanner, D. J., and Huey, L. G: Airborne Cloud Condensation Nuclei Measurements during the 2006 Texas Air Quality Study, J. Geophys. Res., 116, D11201, doi:10.1029/2010JD014874, 2011.

Bardouki, H., Liakakou, H., Economou, C., Sciare, J., Smolik, J., Zdimal, V., Eleftheriadis, K., Lazaridis, M., Dye, C., and Mihalopoulos, N.: Chemical composition of size-resolved atmospheric aerosols in the eastern Mediterranean during summer and winter, Atmos. Environ., 37, 195-208, 2003.

Bilde, M. and Svenningsson, B.: CCN activation of slightly soluble organics: the importance of small amounts of inorganic salt and particle phase, Tellus B, 56, 128-134, 2004.

Bougiatioti, A., Fountoukis, C., Kalivitis, N., Pandis, S. N., Nenes, A., and Mihalopoulos, N.: Cloud condensation nuclei measurements in the marine boundary layer of the eastern Mediterranean: CCN closure and droplet growth kinetics, Atmos. Chem. Phys., 9, 7053-7066, doi:10.5194/acp-9-7053-2009, 2009.

Broekhuizen, K., Kumar, P. P., and Abbatt, J. P. D.: Partially soluble organics as cloud condensation nuclei: role of trace solu- ble and surface active species, Geophys. Res. Lett., 31, L01107, doi:10.1029/2003GL018203, 2004.

Cerully, K. M., Raatikainen, T., Lance, S., Tkacik, D., Tiitta, P., Petäjä, T., Ehn, M., Kulmala, M., Worsnop, D. R., Laaksonen, A., Smith, J. N., and Nenes, A.: Aerosol hygroscopicity and $\mathrm{CCN}$ activation kinetics in a boreal forest environment during the 2007 EUCAARI campaign, Atmos. Chem. Phys. Discuss., 11, 15029-15074, doi:10.5194/acpd-11-15029-2011, 2011.

Chang, R. Y.-W., Liu, P. S. K., Leaitch, W. R., and Abbatt, J. P. D.: Comparison between measured and predicted CCN concentrations at Egbert, Ontario: Focus on the organic aerosol fraction at the semi-rural site, Atmos. Environ., 41, 8172-8182, 2007.

Chuang, P., Charlson, R., and Seinfeld, J.: Kinetic limitations on droplet formation in clouds, Nature, 390(6660), 594-596, 1997.

Cruz, C. N. and Pandis, S. N.: A study of the ability of pure secondary organic aerosol to act as cloud condensation nuclei, Atmos. Environ., 31, 2205-2214, 1997.

Cubison, M. J., Ervens, B., Feingold, G., Docherty, K. S., Ulbrich, I. M., Shields, L., Prather, K., Hering, S., and Jimenez, J. L.: The influence of chemical composition and mixing state of Los Angeles urban aerosol on CCN number and cloud properties, Atmos. Chem. Phys., 8, 5649-5667, doi:10.5194/acp-8-5649-2008, 2008.

Duplissy, J., Gysel, M., Alfarra, M. R., Dommen, J., Metzger, A., Prévôt, A. S. H., Weingartner, E., Laaksonen, A., Raatikainen, T., Good, N., Turner, S. F., McFiggans, G. and Baltensperger, U.: Cloud forming potential of secondary organic aerosol under near atmospheric conditions, Geophys. Res. Lett., 35, L03818, doi:10.1029/2007GL031075, 2008.

Dusek, U., Frank, G. P., Hildebrandt, L., Curtius, J., Schneider, J., Walter, S., Chand, D., Drewnick, F., Hings, S., Jung, D., Borrmann, S., and Andreae, M. O.: Size matters more than chemistry for cloud-nucleating ability of aerosol particles, Science, 312, 1375-1378, 2006.

Dusek, U., Frank, G. P., Curtius, J., Drewnick, F., Schneider, J., Kürten, A., Rose, D., Andreae, M. O., Borrmann, S., and Pöschl, U.: Enhanced organic mass fraction and decreased hygroscopicity of cloud condensation nuclei (CCN) during new particle formation events, Geophys. Res. Lett., 37, L03804, doi:10.1029/2009GL040930, 2010.

Engelhart, G. J., Asa-Awuku, A., Nenes, A., and Pandis, S. N.: $\mathrm{CCN}$ activity and droplet growth kinetics of fresh and aged monoterpene secondary organic aerosol, Atmos. Chem. Phys., 8, 3937-3949, doi:10.5194/acp-8-3937-2008, 2008.

Engelhart, G. J., Moore, R. H., Nenes, A., and Pandis, S. N.: CCN Activity of Isoprene Secondary Organic Aerosol, J. Geophys.Res. , 116, D02207, doi:10.1029/2010JD014706, 2011.

Ervens, B., Feingold, G., and Kreidenweis, S.: Influence of watersoluble organic carbon on cloud drop number concentration, J. Geophys. Res., 110, D18211, doi:10.1029/2004JD005634, 2005.

Gunthe, S. S., King, S. M., Rose, D., Chen, Q., Roldin, P., Farmer, D. K., Jimenez, J. L., Artaxo, P., Andreae, M. O., Martin, S. T., and Pöschl, U.: Cloud condensation nuclei in pristine tropical rainforest air of Amazonia: size-resolved measurements and modeling of atmospheric aerosol composition and CCN activity, Atmos. Chem. Phys. 9, 7551-7575, doi:10.5194/acp-9-75512009, 2009.

Hennigan, C. J., Bergin, M. H., Russell, A. G., Nenes, A., and Weber, R. J.: Gas/particle partitioning of water-soluble or- 
ganic aerosol in Atlanta, Atmos. Chem. Phys., 9, 3613-3628, doi:10.5194/acp-9-3613-2009, 2009.

Hildebrandt, L., Engelhart, G. J., Mohr, C., Kostenidou, E., Lanz, V. A., Bougiatioti, A., DeCarlo, P. F., Prévôt, A. S. H., Baltensperger, U., Mihalopoulos, N., Donahue, N. M., and Pandis, S. N.: Aged organic aerosol in the Eastern Mediterranean: the Finokalia aerosol measurement experiment-2008, Atmos. Chem. Phys., 10, 4167-4186, doi:10.5194/acp-10-4167-2010, 2010.

Intergovernmental Panel on Climate Change, Climate Change 2007: Synthesis Report, 2007.

Jaffrezo J.-L., Avmoz, G., Delaval, C., and Cozic, J.: Seasonal variations of the water soluble organic carbon mass fraction of aerosol in two valleys of the French Alps, Atmos. Chem. Phys., 5, 2809-2821, doi:10.5194/acp-5-2809-2005, 2005.

Jimenez, J. L., Canagratna, M. R., Donahue, N. M., Préevôt, A. S. H., Zhang, Q., Kroll, J. H., DeCarlo, P. F., Allan, J. D., Coe, H., Ng, N. L., Aiken, A. C., Docherty, K. S., Ulbrich, I. M., Grieshop, A. P., Robinson, A. L., Duplissy, J., Smith, J. D., Wilson, K. R., Lanz, V. A., Hueglin, C., Sun, Y. L., Tian, J., Laaksonen,A., Raatikainen, T., Rautiainen, J., Vaattovaara, P., Ehn, M., Kulmala, M., Tomlinson, J. M., Collins, D. R., Cubison, M. J., Dulnea, E. J., Huffman, J. A., Onasch, T. B., Alfarra, M. R., Williams, P. I., Bower, K., Kondo, Y., Schneider, J., Drewnick, F., Borrmann, S., Weimer, S., Demerjian, K., Salcedo, D., Cottrell, L., Griffin, R., Takami, A., Miyoshi, T., Hatakeyama, S., Shimono, A., Sun, J. Y., Zhang, Y. M., Dzepina, K., Kimmel, J. R., Sueper, D., Jayne, J. T., Herndon, S. C., Trimborn, A. M., Williams, L. R., Wood, E. C., Middlebrook, A. M., Kolb, C. E., Baltensperger, U., and Worsnop, D. R.: Evolution of organic aerosols in the atmosphere, Science, 326, 1525-1529, doi:10.1126/sicence.1180353, 2009.

Kalivitis, N., Gerasopoulos, E., Vrekoussis, M., Kouvarakis, G., Kubilay, N., Hatzianastassiou, N., Vardavas, I., and Mihalopoulos, N.: Dust transport over the eastern Mediterranean derived from Total Ozone Mapping Spectrometer, Aerosol Robotic Network, and surface measurements, J. Geophys. Res., 112, D03202, doi:10.1029/2006JD007510, 2007.

Kalivitis, N., Bougiatioti, A., Kouvarakis, G., and Mihalopoulos, N.: Long term measurements of atmospheric aerosol optical properties in the Eastern Mediterranean, Atmos. Res., in review, 2011

King, S. M., Rosenoern, T., Shilling, J. E., Chen, Q., Wang, Z., Biskos, G., McKinney, K. A., Pöschl, U., and Martin, S. T.: Cloud droplet activation of mixed organic-sulfate particles produced by the photooxadation of isoprene, Atmos. Chem. Phys., 10, 3953-964, doi:10.5194/acp-10-3953-2010, 2010.

Kreidenweis, S. M., Petters, M. D., and Chuang, P. Y.: Cloud particle precursors, Clouds in the Perturbed Climate System, in: Their Relationship to Energy Balance, Atmospheric Dynamics, and Precipitation, Strüngmann Forum Report, vol. 2, edited by: Heintzenberg, J. and Charlson, R. J., The MIT Press, Cambridge, MA, 2008.

Kumar, P., Nenes, A., and Sokolik, I.: The Importance of Adsorption for CCN Activity and Hygroscopic Properties of Mineral Dust Aerosol, Geophys. Res. Lett., 36, L24804, doi:10.1029/2009GL040827, 2009.

Kumar, P., Sokolik, I. N., and Nenes, A.: Measurements of cloud condensation nuclei activity and droplet activation kinetics of fresh unprocessed regional dust samples and minerals, Atmos.
Chem. Phys., 11 , 3527-3541, doi:10.5194/acp-11-3527-2011, 2011.

Kuwata, M., Kondo, Y., Miyazaki, Y., Komazaki, Y., Kim, J.H., Yum, S. S., Tanimoto, H., and Matsueda, H.: Cloud condensation nuclei activity at Jeju Island, Korea in spring 2005, Atmos. Chem. Phys., 8, 2933-2948, doi:10.5194/acp-8-2933-2008, 2008.

Lance, S.: Quantifying compositional impacts of ambient aerosol on cloud droplet formation, Doctoral Thesis, Georgia Institute of Technology, 2007.

Lance, S., Nenes, A., and Rissman, T.: Chemical and dynamical effects on cloud droplet number: Implications for estimates of the aerosol indirect effect, J. Geophys. Res., 109, D22208, doi:10.1029/2004JD004596, 2004.

Lance, S., Medina, J., Smith, J., and Nenes, A: Mapping the operation of the DMT continuous flow CCN counter, Aerosol Sci. Technol., 40, 242-254, 2006.

Lance, S., Nenes, A., Mazzoleni, C., Dubey, M. K., Gates, H., Varutbangkul, V., Rissman, T. A., Murphy, S. M., Sorooshian, A., Flagan, T. A., Seinfeld, J. H., Feingold, G., and Jinsson, H.: Cloud condensation nuclei activity, closure, and droplet growth kinetics of Houston aerosol during the Gulf of Mexico Atmospheric Composition and Climate Study (GoMACCS), J. Geophys. Res., 114, D00F15, doi:10.1029/2008JD011699, 2009.

Lathem, T. L. and Nenes, A.: Water vapor depletion in the DMT Continuous Flow CCN Chamber: effects on supersaturation and droplet growth, Aerosol Sci. Tech., 45, 604-615, doi:10.1080/02786826.2010.551146, 2011

Lelieveld, J., Berresheim, H., Borrmann, S., Crutzen, P. J., Dentener, F. J., Fischer, H., Feichter, J., Flatau, P. J., Heland, J., Holzinger, R., Korrmann, R., Lawrence, M. G., Levin, Z., Markowicz, K. M., Mihalopoulos, N., Minikin, A., Ramanathan, V., De Reus, M., Roelofs, G. J., Scheeren, H. A., Sciare, J., Schlager, H., Schultz, M., Siegmund, P., Steil, B., Stephanou, E. G., Stier, P., Traub, M., Warneke, C., Williams, J., and Ziereis, H.: Global Air Pollution Crossroads over the Mediterranean, Science, 298, 794-799, 2002.

Marcolli, C. and Krieger, U. K.: Phase changes during hygroscopic cycles of mixed organic/inorganic model systems of tropospheric aerosols, J. Phys. Chem., 110, 1881-1893, 2006.

Medina, J., Nenes, A., Sotiropoulou, R.-E. P., Cottrell, L. D., Ziemba, L. D., Beckman, P. J., and Griffin, R. J.: Cloud condensation nuclei closure during the International Consortium for Atmospheric Research on Transport and Transformation 2004 campaign: Effects of size-resolved composition, J. Geophys. Res., 112, D10S31, doi:10.1029/2006JD007588, 2007.

Mihalopoulos, N., Stephanou, E., Kanakidou, M., Pilitsidis, S., and Bousquet, P.: Tropospheric aerosol ionic composition above the Eastern Mediterranean area, Tellus B, 49, 314-326, 1997.

Mochida, M., Miyakawa, T., Takegawa, N., Morino, Y., Kawamura, K., and Kondo, Y.: Significant alteration in the hygroscopic properties of urban aerosol particles by the secondary formation of organics, Geophys. Res. Lett., 35, L02804, doi:10.1029/2007GL031310, 2008.

Mochida, M., Nishita-Hara, C., Kitamori, Y., Aggarwal, S. G., Kawamura, K., Miura, K., and Takami, A.: Size-segregated measurements of cloud condensation nucleus activity and hygroscopic growth for aerosols at Cape Hedo, Japan, in spring 2008, J. Geophys. Res., 115, D21207, doi:10.1029/2009JD013216, 
2010.

Moore, R. H., Ingall, E. D., Sorooshian, A., and Nenes, A.: Molar mass surface tension, and droplet growth kinetics on marine organics from measurements of CCN activity, Geophys. Res. Lett., 35, L07801, doi:10.1029/2008GL033350, 2008.

Moore, R., Nenes, A., and Medina, J.: Scanning Mobility CCN Analysis: A method for fast measurements of size-resolved CCN distributions and activation kinetics, Aerosol Sci. Technol., 44, 861-871, 2010.

Murphy, S. M., Agrawal, H., Sorooshian, A., Padró, L. T., Gates, H., Hersey, S., Welch, W. A., Jung, H., Miller, J. W., Cocker, D. R., Nenes, A., Jonsson, H., Flagan, R. C., and Seinfeld, J. H.: Comprehensive Simultaneous Shipboard and Airborne Characterization of Exhaust from a Modern Container Ship at Sea, Environ. Sci. Techol., 43, 4626-4640, 2009.

Nenes, A., Ghan, S., Abdul-Razzak, H., Chuang, P. Y., and Seinfeld, J. H.: Kinetic limitations on cloud droplet formation and impact on cloud albedo, Tellus B, 53, 133-149, 2001a.

Nenes, A., Chuang, P. Y., Flagan, R., and Seinfeld, J. H.: A Theoretical Analysis of Cloud Condensation Nucleus (CCN) Instruments, J. Geophys. Res., 106, 3449-3474, 2001 b.

Nenes, A. Charlson, R. J., Facchini, M. C., Kulmala, M., Laaksonen, A., and Seinfeld, J. H.: Can Chemical Effects on Cloud Droplet Number Rival the First Indirect Effect?, Geophys. Res. Lett., 29(17), 1848, doi:10.1029/2002GL015295, 2002.

Niedermeier, D., Wex, H., Voigtländer, J., Stratmann, F., Brüggemann, E., Kiselev, A., Henk, H., and Heintzenberg, J.: LACIS-measurements and parameterization of sea-salt particle hygroscopic growth and activation, Atmos. Chem. Phys., 8, 579590, doi:10.5194/acp-8-579-2008, 2008.

Padró, L. T. and Nenes, A.: Cloud droplet activation: solubility revisited, Atmos. Chem. Phys. Discuss., 7, 2325-2355, doi:10.5194/acpd-7-2325-2007, 2007.

Padró, L. T., Asa-Awuku, A., Morrison, R., and Nenes, A.: Inferring thermodynamic properties from $\mathrm{CCN}$ activation experiments: single-component and binary aerosols, Atmos. Chem. Phys., 7, 5263-5274, doi:10.5194/acp-7-5263-2007, 2007.

Padró, L. T., Tkacik, D., Lathem, T., Hennigan, C. J., Sullivan, A. P., Weber, R. J., Huey, L. G., and Nenes, A.: Investigation of cloud condensation nuclei properties and droplet growth kinetics of the water-soluble aerosol fraction in Mexico City, J. Geophys. Res., 115, D09204, doi:10.1029/2009JD013195, 2010.

Petters, M. D. and Kreidenweis, S. M.: A single parameter representation of hygroscopic growth nad cloud condensation nucleus activity, Atmos. Chem. Phys., 7, 1961-1971, doi:10.5194/acp-71961-2007, 2007.

Pöschl, U., Rose, D., and Andreae, M.O.: Climatologies of Cloudrelated Aerosols. Part 2. Particle Hygroscopicity and Cloud Condensation Nuclei Activity, Clouds in the Perturbed Climate System: their relationship to Energy Balance, Atmospheric Dynamics and Precipitation, Strüngmann Forum Report, vol. 2, edited by: Heitzenberg, J. and Charlson, R. J., The MIT Press, Cambridge, MA, 2008.

Quinn, P. K., Bates, T. S., Coffman, D. J., and Covert, D. S.: Influence of particle size and chemistry on the cloud nucleating properties of aerosols, Atmos. Chem. Phys., 8, 1029-1042, doi:10.5194/acp-8-1029-2008, 2008.

Raymond, T. M. and Pandis, S. N.: Cloud activation of singlecomponent organic aerosol particles, J. Geophys. Res., 107,
4787, doi:10.1029/2002JD002159, 2002.

Raymond, T. M. and Pandis, S. N.: Formation of cloud droplets by multicomponent organic particles, J. Geophys. Res., 108, 4469, doi:10.1029/2003JD003503, 2003.

Roberts, G. and Nenes, A.: A continuous-flow streamwise thermalgradient CCN chamber for atmospheric measurements, Aerosol Sci. Technol., 39, 206-221, 2005.

Roberts, G. C., Artaxo, P., Zhou, J. C., Swietlicki, E., and Andreae, M. O.: Sensitivity of CCN spectra on chemical and physical properties of aerosol: A case study from the Amazon Basin, J. Geophys. Res., 107, 8070, doi:10.1029/2001JD000583, 2002.

Rose, D., Gunthe, S. S., Mikhailov, E., Frank, G. P., Dusek, U., Andreae, M. O., and Pöschl, U.: Calibration and measurement uncertainties of a continuous-flow cloud condensation nuclei counter (DMT-CCNC): CCN activation of ammonium sulfate and sodium chloride aerosol particles in theory and experiment, Atmos. Chem. Phys., 8, 1153-1179, doi:10.5194/acp-8-11532008, 2008.

Rose, D., Nowak, A., Achtert, P., Wiedensohler, A., Hu, M., Shao, M., Zhang, Y., Andreae, M. O., Poeschl, U.: Cloud condensation nuclei in polluted air and biomass burning smoke near the mega-city Guangzhou, China - Part 1: Size-resolved measurements and implications for the modeling of aerosol particle hygroscopicity and CCN activity, Atmos. Chem. Phys., 10, 3365 3383, doi:10.5194/acp-10-3365-2010, 2010.

Ruehl, C. R., Chuang, P. Y., and Nenes, A.: Distinct CCN activation kinetics above the marine boundary layer along the California coast, Geophys. Res. Lett., 36(15), L15814, doi:10.1029/2009GL038839, 2009.

Ruehl, C. R., Chuang, P. Y., and Nenes, A.: How quickly do cloud droplets form on atmospheric particles?, Atmos. Chem. Phys., 8, 1043-1055, doi:10.5194/acp-8-1043-2008, 2008.

Sciare, J., Bardouki, H., Moulin, C., Mihalopoulos, N.: Aerosol sources and their contribution to the chemical composition of aerosols in the Eastern Mediterranean Sea during summertime, Atmos. Chem. Phys., 3, 291-302, doi:10.5194/acp-3-291-2003, 2003.

Shantz, N. C., Leaitch, W. R., Phinney, L., Mozurkewich, M., and Toom-Sauntry, D.: The effect of organic compounds on the growth rate of cloud droplets in marine and forest settings, Atmos. Chem. Phys., 8, 5869-5887, doi:10.5194/acp-8-5869-2008, 2008.

Sotiropoulou, R. E. P, Medina, J., Nenes A.: CCN predictions: is theory sufficient for assessments of the indirect effect?, Geophys. Res. Lett., 33, L05816, doi:10.1029/2005GL025148, 2006.

Sotiropoulou, R. E. P, Nenes, A., Adams, P. J., and Seinfeld, J. H.: Cloud condensation nuclei prediction error from application of Kohler theory: Importance for the aerosol indirect effect, J. Geophys. Res., 112, D12202, doi:10.1029/2006JD007834, 2007.

Sorooshian, A., Murphy, S. M., Hersey, S., Gates, H., Padro, L. T., Nenes, A., Brechtel, F. J., Jonsson, H., Flagan, R. C., and Seinfeld, J. H.: Comprehensive airborne characterization of aerosol from a major bovine source, Atmos. Chem. Phys., 8, 5489-5520, doi:10.5194/acp-8-5489-2008, 2008.

Vrekoussis, M., Liakakou, E., Koçak, M., Kubilay, N., Oikonomou, K., Sciare, J., and Mihalopoulos, N.: Seasonal variability of optical properties of aerosols in the Eastern Mediterranean, Atmos. Environ., 39, 37, 7083-7094, 2005.

Wang, S. and Flagan, R.: Scanning electrical mobility spectrometer, 
J. Aerosol Sci., 20, 1485-1488, 1989.

Wang, J., Cubison, M. J., Aitken, A. C., Jimenez, J. L., and Collins, D. R.: The importance of aerosol mixing state and size-resolved composition on $\mathrm{CCN}$ concentration and the variation of the importance with atmospheric aging of aerosols, Atmos. Chem. Phys., 10, 7267-7283, doi:10.5194/acp-10-7267-2010, 2010.

Weber, R. J., Sullivan, A. P., Peltier, R. E., Russell, A., Yan, B., Zheng, M., deGouw, J., Warneke, C., Brock, C., Holloway, J. S., Atlas, E. L., and Edgerton, E.: A study of secondary organic aerosol formation in the anthropogenicinfluenced southeastern United States, J. Geophys. Res., 112, D13302, doi:10.1029/2007JD008408, 2007.

Wiedensohler, A., Technical note: An approximation of the bipolar charge distribution for particles in the submicron range, J. Aerosol Sci., 19, 387-389, 1988.
Wiedensohler, A., Cheng, Y. F., Nowak, A., Wehner, B., Achtert, P., Berghof, M., Birmili, W., Wu, Z. J., Hu, M., Zhu, T., Takegawa, N., Kita, K., Kondo, Y., Lou, S. R., Hofzumahaus, A., Holland, F., Wahner, A., Gunthe, S. S., Rose, D., Su, H., and Pöschl, U.: Rapid aerosol particle growth and increase of cloud nucleus activity by secondary aerosol formation and condensation: A case study for regional air pollution in northeastern China, J. Geophys. Res., 114, D00G08, doi:10.1029/2008JD10884, 2009.

Zhang, Q., Jimenez, J. L., Canagaratna, M. R., Allan, J. D., Coe, H., Ulbrich, I., Alfarra, M. R., Takami, A., Middlebrook, A., Sun, Y. L., Dzepina, K., Dunlea, E., Docherty, K., DeCarlo, P. F., Salcedo, D., Onasch, T., Jayne, J. T., Miyoshi, T., Shimono, A., Hatakeyama, S., Takegawa, N., Kondo, Y., Schneider, J., Drewnick., F., Borrmann, S., Weimer, S., Demerjian, K., Williams, P., Bower, K., Bahreini, R., Cottrell, L., Griffin, R. J., Rautiainen, J., Sun, J. Y., Zhang, Y. M., and Worsnop, D. R.: Ubiquity and dominance of oxygenated species in organic aerosols in antropogenically-influenced Northern Hemisphere midlatitudes, Geophys. Res. Lett., 34, L13801, doi:10.1029/2007g1029979, 2007. 